\title{
Didactic in Continental European pedagogy: An analysis of its origins and problems
}

\author{
Sümer Aktan ${ }^{* a}$, Harun Serpil ${ }^{* *}$ \\ a Balıkesir University, Necatibey Faculty of Education, Balıkesir/Turkey \\ ${ }^{\mathrm{b}}$ Anadolu University, School of Foreign Languages, Eskişehir/Turkey
}

Article Info

DOI: 10.31704/ijocis.2018.006

Article History:

Received 27 April 2018

Revised 07 June 2018

Accepted 21 June 2018

Online $\quad 30$ June 2018

\section{Keywords:}

Didactic,

Humanist pedagogy,

Continental Europe,

Curriculum.

Article Type:

Review

\begin{abstract}
The aim of this study is to describe, in a historical and philosophical context, the foundations and developmental lines of a tradition defined as curriculum science or "didactic" in Continental Europe, particularly in Germany and Scandinavia. The principal aim here is introducing a theoretical approach based on a different philosophy, in addition to the techno-scientific Anglo-American theoretical approach. Didactic tradition has been of particular interest for curriculum researchers especially in the past two decades. With such an interactive focus, this paper is divided into four sections. Because this paper traces historical and philosophical pathways of inquiry, its research method is purely qualitative, based on document analysis. The findings of this analytical study are expected to contribute to the wider recognition of a philosophical-pedagogical tradition, which has not hitherto been paid much attention in Turkey.
\end{abstract}

\section{Kıta Avrupası pedagojisinde didaktik: Temelleri ve problemleri üzerine bir inceleme}

Makale Bilgisi

DOI: 10.31704/ijocis.2018.006

Makale Geçmişi:

Geliş 27 Nisan 2018

Düzeltme 07 Haziran 2018

Kabul 21 Haziran 2018

Çevrimiçi 30 Haziran 2018

Anahtar Kelimeler:

Didaktik,

Hümanist pedagoji,

Kıta Avrupası,

Öğretim Programı.

Makale Türü:

Derleme
Öz

Bu çalışmanın amacı, Kıta Avrupası ve özellikle Almanya ve İskandinav ülkelerinde öğretim bilimi veya didaktik olarak tanımlanan bir geleneğin temellerini ve gelişim çizgisini tarihsel ve felsefi bağlam içinde betimlemektir. Araştırmanın hedef kitlesi program teorisi alanında çalışanlardır. Anglo-Amerikan teknik bilimsel teorik yaklaşımın yanında farkı bir felsefeye dayalı, farklı bir teorik boyutun tanıtılması esas amaçtır. Didaktik gelenek eğitim programları ve öğretim alanında özellikle son yirmi yıllık zaman diliminde dikkatleri çeken bir araştırma konusudur. Bu etkileşimli bağlam içerisinde çalışma dört parça halinde kurgulanmıştır. Çalışma tarihsel ve felsefi bir bağlamı izlediği için nitel araştırma geleneği içinde doküman analizine dayalı olarak yapılandırılmıştır. Araştırmanın bulgularının Türkiye'de çok üzerinde durulmayan bir felsefi pedagojik geleneğin tanınmasına katkıda bulunacağı düşünülmektedir.

\footnotetext{
* Author: saktanus@gmail.com

** Author: hserpil@anadolu.edu.tr
}

Orcid ID: https://orcid.org/0000-0003-2938-7782 Orcid ID: https://orcid.org/0000-0002-6293-9385 


\section{Introduction}

Considering its usage in the Turkish and English contexts, the word "didactic" does not seem to have any positive connotations. Expressing an interaction based on a certain discipline between the teacher and the student, this word is often used negatively in the literature of education research (Kansanen, 1995; Westbury, 2000). As the dominant paradigm in the field of curriculum and instruction, an Anglo-American perspective appears to dictate the definition of almost all concepts (Pinar, Reynolds, Slattery, \& Taubman, 2008; Tahirsylaj, 2017). However, especially in the context of the internationalization of curriculum studies, attempts to determine new and different perspectives seem to be gaining ground as well. For example, the reconceptualization which began to develop at the beginning of the 1970s, the Neo-Marxist curriculum analyses, critical theory, and poststructuralist curriculum thought, can be given as some examples for these new perspectives. In addition to these diverse perspectives emerging in the curriculum theory, approaches that are developed in relation to different philosophical traditions addressing the paradigm of curriculum and instruction from different angles, especially with regards to the internationalization of curriculum studies have drawn attention. As such, the didactic tradition dominant in the Continental Europe and Scandinavian educational thought has been carefully studied as a new venue of research in the field of curriculum and instruction (Deng, 2015, 2016; Gundem, 2000; Kansanen, 1995; Künzli, 1998, 2013; Kruger, 2008; Westbury, Hopmann \& Riquarts, 2000). What is the meaning of this concept attracting such considerable attention in the field of curriculum and instruction? What does "didactic" really mean and how does it differ from the AngloAmerican curriculum paradigm? When the root and philosophical context of the word "didactic" is examined, it becomes clear that it is an important conceptual approach that directs the teaching process. It can be described both as a science that comprises all the variables of the learning and teaching process including the formal / informal dimension (Dolch, 1965 cited in Gundem, 2000), and as a method used for the formation of the new generations through education. The origins of this word can be traced back to the ancient Greek word "didaskein/didaskio" meaning "to be a teacher" or "to teach" (Antel, 1952; Hopmann, 2007). Over time, this meaning has expanded to include more comprehensive and detailed connotations. When the evolution of this concept is examined, it can be seen that there is a certain meaning attached to it that has been developing since the time of Plato and Aristotle, expanded by Thomas Aquinas, Hugh of Saint Victor, Quintillianus, Comenius and Racitus. In particular, the Didaktika Magna written by Comenius was the first systematic work on the subject published in Europe (Hopmann, 2007). Unlike his predecessors, Comenius conceptualized "didactic" as the sequencing of the education process. More recently, in addition to the contributions made by some German educators like Salzmann and Basedow, Herbart has also made remarkable contributions to the development of didactic by following in the footsteps of Swiss educator Pestalozzi. However, the development of a philosophical approach to the didactic perspective, and thus the birth of a rich philosophical sociopedagogical orientation has become possible only through Wilhelm Dilthey's humanist pedagogy. The theoretical framework of our study is this humanist pedagogy [Geistteswisseschaftliche Padagogik]. This paper is outlined as a four distinct yet interrelated sections. The first part describes the historical development of didactic. The second part focuses on the contributions made by Herbartian pedagogy to didactic. The third section discusses the concept of "Bildung" and its contributions to the didactic perspective in its Diltheyan sense. The fourth part compares the Anglo-American Curriculum and instruction perspective with that of the didactic.

\section{Research on Didactic in Turkey}

Studies on didactic issues in Turkey focus largely on teacher training and teaching processes. In other words, they mostly pertain to subject-specific teacher education and the teaching processes of all the subjects. Regarding the studies that focus on didactic in the context of teacher education, Baki (2010) analyzes didactic in terms of subject-specific teaching competencies. He underscores the importance of didactic in teaching subjects, and the relationship between teacher education and subject teaching. However, his study does not include any discussion of the historical or philosophical contexts, but instead merely focuses on a particular instructional context. In their study, Yıldırım and Vural (2014) focus on the problem of teacher training and pedagogical formation (teaching certification), in which didactic is mentioned only once. Under the title "Finnish Model in Teacher Training," the authors mention didactic as part of Finnish teachers' pre-service training. The historical, social and philosophical aspects of didactic are not discussed in this study either. Gök and Erdoğan's (2017) study adapted the didactic situations theory to the field of mathematics teaching, as one strand of the field of general didactics for subject teaching. The subject didactics, one of the two main aspects of didactics, is a study of different approaches to the teaching of any academic subject. Their study does not 
touch upon the philosophical and historical evolution of didactic either. Another similar study on the theory of didactic situations was conducted by Baştürk Şahin, Şahin and Tapan Broutin (2017), who used didactic only as an approach to teach a subject (mathematics), and did not include any discussions of the developmental process or historical background of didactic. In the research conducted by Yurdatapan and Şahin (2012), "didactic transformation theory" was used in the evaluation of teacher knowledge, and the reflection of the transposed didactic approach, a dominant approach in the French didactic tradition, is emphasized in subject teaching. An overall analysis of the didactic research literature in Turkey thus indicates that didactic is mostly used to carry out research on subject teaching or content knowledge, but no conceptual framework is provided about what didactic really is. Therefore, the current study is expected to fill this extant gap in the Turkish research literature.

\section{Method}

This is a qualitative study that examines the development and origins of didactic in continental Europe. Qualitative research is generally used for an in-depth study of the facts or phenomena. It aims to describe the historical roots of didactics and its development in a philosophical context. The main data source for this study is the related literature. The literature was analyzed via document analysis, which is a qualitative research method used in analyzing the relevant literature with specific techniques. The method of document analysis involves the collection of data from written materials containing information on the cases or phenomena targeted for investigation in a form suitable for the purpose of research (Yıldırım and Şimşek, 2008). For document analysis, the literature regarding the specific research problem is of great importance. Obtaining the related literature according to the purpose of the problem is the first step in document analysis. The books included in the literature used in this study were obtained by accessing as many original copies as possible, and certain parts of the works without accessible original copies were used as they pertain to the research problem. Although indexed journals were preferred as the sources for the cited articles, some web pages were also utilized. The article searches were based on keywords, and the full-length articles cited in the bibliographies of the key didactic books were obtained from various university databases. In the research process, a literature review regarding the research problems was carried out and the necessary resources were categorized. Each resource was critically read and coded vis-à-vis the research problems. The notes classified according to the coding were then used in the analysis of each problem. In the document analysis, it was first tested whether the obtained literature was related to the problems of the research in order to ensure its reliability and validity. In this process, researchers explored the sources separately, and sought a consensus on the adequacy of the obtained literature sources. In addition, agreement on the code and the themes revealed by the research problems was sought. Further consensus was also ensured for the notes taken about the literature regarding their relevance to the research problems. The research problems of this study are the following: (1) What trajectory has didactic followed in the historical continuity? (2) What are the contributions made by Herbartian pedagogy to didactic? (3) How have the relationships of the humanist pedagogy with didactic developed? (4) What are the similarities and differences between the Didactic tradition and the AngloAmerican curriculum thought? Our study was designed to answer these four questions.

\section{The Evolution of Didactic}

Hopmann (2007) proposed a conceptual framework that clearly defines the historical evolution of didactic. According to this framework, the historical development of didactic was driven by three main concepts which are ordering, sequencing and selection. The first step in the development of didactic concerns the question of how to determine the order of the subjects to be taught. In other words, how should the subject be systematized, and what kind of order should be followed in its presentation to the student? This specific meaning of the concept is found in the texts by Plato and Aristotle of the Ancient Greece. In the dialogue called "Meno," Socrates explains how to solve a geometry problem to a slave. In their dialogue, the only thing Sokrates does is asking the slave meaningful questions that progress in a certain order. Each answer given to a question raises another question. While the point made by Socrates here demonstrates the epistemology of the idealist philosophy, it actually underlines the key dimensions of the teaching process (Jarvis, 2006). When didactic is approached from Socrates' perspective, the primary role of the teacher is initiating and facilitating the interaction between the learner and the content. The content becomes meaningful through the questions asked by the teacher during the learning process. With its origins in the Ancient Greece, how was the didactic approach transferred to Europe? 
The heritage of the ancient Greek civilization was transferred to Europe by the Islamic world (Gutas, 1999; Hodgson, 1974; Makdisi, 1981). In this transfer process, Europe learned about the ancient Greek classics, but more importantly, it was introduced to the cultural contributions made by the Arab-Andalusians. This heritage played a significant role in Europe's rise out of its Dark Age (Saliba, 2007). Naturally, European thinkers were influenced by the Islamic civilization's view of learning and teaching. This influence bears the marks of some important Middle Age philosophers' perspectives on the teaching process. In other words, didactic became a problem of European philosophers in the middle ages. For these philosophers who taught Dominican and Franciscan schools of thought in the monasteries, didactic played a key role in allowing them to grasp some difficult and ambiguous issues. One of these philosophers, Hugh of Saint Victor, was one of the first to study didactic. Hugh describes the teaching process as a disciplined action and emphasizes that learning can take place only through a disciplined process in a disciplined environment (Hopmann, 2007; Roest, 2000; Rorem, 2009). Another Catholic philosopher, Thomas Aquinas, developed Hugh's thoughts further. In his work titled "Summa Theologica," he underscores the importance of the learner's active role in the learning process, and defines the teacher as a person helping the student in this process (Copleston, 1962; DeWulf, 1959).

The second step in the evolution of didactic is sequencing, which appeared during the reform era in Europe. After the Renaissance, especially after the struggle with the church, the events that took place during the reform era caused the didactic to acquire a new dimension. The bloody fights against the Catholic Church brought a major breakthrough in terms of the spread of Protestantism. A more important development than this spread of Protestantism was the quest that began in the field of education and social welfare (Lindberg, 2010). The most important result of this quest was the debate about the nature of the teaching process. Obviously, the thinker who made the most significant contribution to the didactic thinking of the reform era is Comenius. This Protestant pastor of the Czech Republic, who lived between 1592 and 1670, is perhaps one of the greatest thinkers leaving an indelible mark on the history of pedagogy and didactic. For Comenius, who lived in Europe in a time of a rapid pace of reform, schools were vitally important for the happiness of society and for the development of Christianity. For Comenius, who saw education as the main driver of social development, the most urgent problem was the inefficient and useless education delivered at schools. The most important dilemma of this useless education was the teaching methods. If reforms could be made in methods, schools could be the places where the light would shine and dissipate the darknesses. As a first step in solving these problems, he wrote a course book. It is possible to find the earliest foundations of didactics in this work bearing the name of Orbis Sensualium Pictus. In this book, with short stories, Comenius gradually introduces the world to young children. Written by him later, and elaborating on the pedagogical principles of "from closer to farther" and "from known to unknown," which are used in teaching even today, Didactica Magna is one of the pioneering books explaining the basic principles of didactic (Leek, 2011; Lukaš \& Munjiza, 2014). Comenius describes his own didactic system in terms of the interrelationship among three Latin concepts: Omnes, omnia and omnino (Siljander \& Sutinen, 2012). Omnes [Everybody] signifies the school system. Beginning from childhood, a graded education system must be designed for everybody. Thus, Omnes means "an individual to be educated." Omnia means knowledge [everything or all kinds of information]. It is only possible for individuals to be enlightened if they have knowledge. Omnino [with all perceptions] refers to the method (Gundem, 1992; Menck, 2014). Therefore, the relationship between the teacher and the learner is built through knowledge forms the basis of didactic. In this relationship, Comenius views sequencing as the key concept. The presentation of information to the learner in small pieces and in stages is the essence of Comenian didactic. Comenius states the basic aims of didactic as follows:

The following must be the primary purposes of our education: finding a teaching method whereby teachers teach less but learners learn more, and turning the schools into the environments where instead of noisiness, reluctance, and waste of effort more pleasant time and a definite development prevail. In this way, the Christian community can be redeemed from the darkness, confusion, and disorder, and reach light, peace, and order (Comenius, 1907, p.5).

The third step in the evolution of didactic is selection. Didactic constitutes the basis of what to teach students. However, didactic did not have this meaning until the end of the 18th century and the beginning of the 19th century. The Seven Year Wars that affected the whole of Europe, followed by the French Revolution and the Napoleonic wars in the following years led to a debate on what to teach the new generations in order to help them fight the chaos in Europe. The idea of teaching useful information, as stressed by Comenius, instead of teaching everything to everyone resulted in an expansion in the meaning of didactic. This idea was first applied by the Prussians. In the Prussian state, while the education bureaucracy was being created, some important regulations and directives were made about how teachers were to give lessons and what to look for 
when choosing subjects (Blackbourn, 1998; Levinger, 2000). With these arrangements of the Prussian education bureaucracy, the first written curriculum was officially created by the state (Hopmann, 2007). Goodson (2004) and Westbury et al (2016) share the same view, who see the plan [Normalplan für Gymnasien] implemented by Prussia right after the Waterloo Battle in 1816 as a comprehensive effort by the state with the aim of making education a social product. With this plan, curricula were prepared by the government in accordance with school levels, textbooks were printed, schedules were organized, and some detailed rules were made regarding the prizes and examinations to be given. Thus, the selection of knowledge was included among the basic meanings of didactic. Indeed, this was nothing more than asking, in continental Europe, "What knowledge is of most worth?" which was also asked by Herbert Spencer in the Anglo-Saxon world. For the first time in continental Europe, education had become a social product and the reconstruction of new generations by subjecting them to a certain cultural formation (shaping) took place in Germany. The effectiveness and efficiency of such a formation process is a systemic and structural problem. Didactic attempts to solve this problem, which is at the nexus of all actions to be performed regarding schools. The basic function of didactic is to make sure the schools effectively perform their task of shaping the individuals in a cultural, mental and spiritual sense. However, before this task can be accomplished, this cultural shaping needs to be philosophically analyzed. This is the point that the concept of Bildung comes into play. This concept, which is translated in to English simply as "education," and into Turkish as "terbiye" or "eğitim," is undergirded by some profound meanings and philosophical implications. Eduard Spranger, a prominent 20th century pedagogue, defines the concept of Bildung as follows:

"Bildung' is the formation of an individual's essence which is acquired by cultural influences and which is homogeneous, structured, and suitable to be developed; this formation of his essence enables the individual to objectively valuable cultural achieve ments, and it enables him to experience (to comprehend) objective cultural values. Bildung' "is formation of the individual's essence; for, we would not consider transient characteristics as 'Bildung'... Further, 'Bildung' is homogeneous and structured, i.e. manifold and yet comprehensive. A person with a quite one-sided psychic culture would not be called 'gebildet' (educated); but also not the multi-sided one, who is dispersing to all directions without contours and who has no centre, no firm essence, no form." Real 'Bildung' always contains "developmental dispositions and continuous growth, because principally, it is nothing else than a refined result of development... This refinement is achieved by cultural influences... By the cultural influences themselves, an objective content of value is represented..."They enable the person to understand a cultural content on the one hand; on the other hand, they rouse in himself value-creating forces which again transform understanding and experience to objective cultural values (achievements)... For these experiencing and creative forces there must also exist a personal centre, and by relating the cultural values to it in a homogenous way, the raw individuality rises to a formed individuality or to a fully educated ('gebildete') personality (Spranger, 1968, pp.24-26).

During its development in continental Europe, Didactic's crossing paths with Bildung was quite crucial. Bildung, as a concept produced in the cultural context of the German pedagogy, has brought the didactic perspective to a more sophisticated level. At this stage, the significant roles played by Comenius and Wolfgang Ratke in building the German didactic is of particular notice. Both of them shared the common goal of finding a method to build the teaching process in an efficient and effective way (Kansanen, 1995). The German didactic perspective, developing under the leadership of Ratke, gradually assumed a new meaning colored by the concept of Bildung. This movement, especially guided by the idealistic character of the German philosophy, has led to the formation of a rich pedagogical accumulation and the development of the different dimensions of the didactic. In this developmental process, especially the end of the 18th century and the 19th century witnessed some significant events. This period was crucial in the process of didactic's integration into the human sciences or humanist pedagogy. Regarding this process, the first thing to analyze here is Johann Fredrich Herbart and the Herbartian didactic that was later refined and systematized by his followers.

\section{Herbart and the Herbartian Didactic}

Johann Fredrich Herbart (1776-1841) is a systematic and doctrinal philosopher who made a significant contribution to the development of American pedagogy with his views, and left behind an important didactic legacy in the history of pedagogy (Hilgenheger, 1993; Gutek, 2013). His most important contribution was making pedagogy a scientific and systematic field of study, based on the scientific principles applied since Locke. In other words, he pioneered the formation of the scientific pedagogy. For Herbart, scientific means a rational, logical and philosophical system. Science is not used here in a positivist sense but in an idealistic 
philosophical context. Undoubtedly, Herbart's contribution to the field of didactic is his synthesizing the Bildung concept with didactic, and constructing the theory of an approach called "educative instruction." The basic aim of Didactic is to present the teaching process in a rational and logical system, order, and sequencing. This Bildung process is possible not only by implementing certain technical steps but also providing a comprehensive structure. That is, didactic must consider some key variables to be able to realize the Bildung. Egemen (1965) defines three of these key variables as the administration, teaching and discipline. Administration refers to the child's protection from all kinds of harmful effects in the school environment, ensuring obedience, and getting him/her accustomed to a certain organizational order. Teaching refers to all kinds of actions towards making the child well-behaved, knowledgeable, and skillful. The purpose of teaching, for Herbart, is to discipline/ educate (Bildung) the child. An education that only provides dry facts without instilling discipline, making certain habits adopted, and ensuring the learner's adaptation to the social environment is not really education. Discipline means that these formative processes of the individual take place within a certain system. Therefore, it is not possible to talk about any character formation without a system.

Another remarkable dimension of this theory proposed by Herbart is the system that it introduced to didactic. Called "Formal Steps," Herbart outlines a framework to serve the purposes of the Bildung. According to this framework, for a course to be educative, it needs to include the steps of (1) Preparation, (2) Presentation, (3) Association, (4) Sistematization, and (5) Application (Herbart, 1904, p.59). These steps proposed by Herbart for the didactic process were to make teaching both more effective and efficient, which had been an objective since Comenius' time. However, the Herbartian didactic, although criticized for limiting the teaching process to a mechanical dimension and thus killing creativity, achieved something that could not have been achieved up to that point and transformed didactic into a methodology. In the post-Herbart period, his followers, especially Tuiskon Ziller, Wilhelm Rein, and Ludwig Strümpell made great contributions to the improvement of the Herbartian didactic theory. While it was later overshadowed by the Work School (Arbeitschule) especially from the 20th century onwards, thanks to this humanist pedagogical reinterpretation, it achieved the recognition it deserved. Approached as a certain technical process by Herbart, Didactic assumed a deeper philosophical character as illuminated with the humanist pedagogy. This philosophical character contributed to an effective and in-depth debate of a wide range of educational concepts, while paving way for the growth of diverse didactic perspectives. Wolfgang Klafki and Eric Weniger, two of the most influential didactic theoreticians of the 20th century, are among the most distinguished architects of this process. Wilhelm Dilthey and his approach to human sciences contributed to the birth of a new pedagogical tradition: humanist pedagogy.

\section{Humanist Pedagogy and Didactic}

Arguably, the most important point in the historical development of the didactic approach is its integration into the German pedagogy. Indeed, a critical analysis of the history of pedagogy reveals that the German pedagogy followed a different course in the evolution of education as a science distinct from philosophy. Notably, this line of development of the German pedagogy created the basis for a strong pedagogical discourse that had a clear impact on the American pedagogy in the 1875-1925 period (Gutek, 2013; McNeil, 2015; Ohles, 1978). The development of the humanist educational science is vital to understand the roots of Didactic, since the most fruitful interaction of Didactic with Bildung was enabled by the humanist pedagogy, even if it was adopted by different schools of thought in the 20th century.

While the humanist pedagogy has deep philosophical roots, its major development occurred in the 19101920 period. The humanist pedagogy, based on the philosophical-historical work of Friedrich Schleiermacher (1768-1864) and Wilhelm Dilthey (1833-1911), was intellectually refined into a more systematic structure in this period. Therefore, while its systematization was realized in the early 20th century, this pedagogical approach was dominant in the 19th century Germany. Contributing to the formation of a very important tradition, the humanist pedagogy also contributed to the creation of a rich perspective within the Didactic tradition. Herman Nohl, Theodor Litt, Eduard Spranger, Wilhelm Flitner and Erich Weniger are some of the leading pedagogues and didacticians of this humanist school. Nohl and Weniger's followers Wolfgang Klafki and Klaus Mollenhauer, who represent another branch of this school called "Göttingen School," are some of the first names that come to mind regarding Didactic (Biesta, 2013; Van Manen, 2015; Wulf, 2014). Tröhler (2003) explains the developmental process of humanistic pedagogy [Geisteswissenschaftliche Padagogik] on the basis of some factors like institutional literature and scientific publishing. The strongest among these factors is the central role played by idealist philosophy in the German philosophical tradition. The strong effect of idealism 
on the German literature, and its treatment of humans as spiritual beings had a significant impact on the evolution of humanist pedagogy. Particularly, Wilhelm Dilthey's conceptualization of it brought a new dimension to the development of this tradition. Therefore, Dilthey's interpretations can be said to lie at the heart of the humanist pedagogy and Didactic. Dilthey reinterpreted the idealistic philosophy with a historical and human-centered perspective. According to Dilthey, the human is a historical, social and cultural entity, and therefore, understanding the human can only take place in a historical, social and cultural context. The main characteristic that makes a human a human is his/her historical entity. All artifacts [artificial facts] produced by man, that is, language, art, philosophy, law, literature, and education, only have meaning in a certain sociocultural context with their specific historical time frame and historical identity attached to them (Bulhof, 1980). Education and all concepts related to education are a part of this world of meaning as well. Pedagogy has an important place in the human sciences because it refers directly to the human being - with sorrows, pains, worries and joys. Therefore, for Dilthey, pedagogy is not a natural science but a human science. With this perspective, he vehemently opposes to the classical positivist definition of humans and science. For Dilthey, the task of the pedagogy is to determine how homogeneous the structure within which a historical social reality emerges at a specific time is, to identify the nature of the elements that affect it based on the contributions of these elements to the formation of this homogenous structure, and to discover the unique dimensions of this social historical reality by defining the factors governing its development. Only in this way the human nature can be understood, and the effect of all the artifacts on the human can be analyzed. It can be used to examine the context of student and teacher relations in the class, as well as the elements that influence the actualization of the didactic process. As the key concerns of Didactic, the selection of content to be taught, the systematization of the content, and the learning of it through interactions with the students are also among the most important issues that such a human sciences pedagogy emphasizes. Curricula and textbooks, which guide the teaching process in schools, are prepared by adults on the basis of certain ideological and ethical beliefs, determining the way schools educate the future citizens. The analysis of this process in terms of the learner, the content and the teacher, should be carried out philosophically. The method used here is hermeneutic. Thus, human sciences pedagogy accepts hermeneutics as its primary method. The humanist pedagogy describes all its concepts, including didactic, from this hermeneutical perspective. The definition of education by Herman Nohl, who has an important place in this tradition, aligns with this perspective as well. According to Nohl (1949), education is the relationship between an adult and a developing entity that perceives and shapes its own life. Once education has been defined in this way, the didactic perspective becomes clearer. With this definition of education, Nohl (1949) manifests his belonging to a different philosophical world. However, a different philosophical world is also present in the Anglo-American curriculum and instruction field. These two traditions try to solve similar problems with different questions.

\section{Curriculum and Didactic: Different Questions but the Same Phenomena}

Didactic is a field that emphasizes the philosophical dimension of understanding the nature of the learning and teaching process as a fundamental problem, but at the same time examines the processes involved in a socio-pedagogical perspective. Not satisfied with the technical analyses of the teaching process, this approach advocates for an in-depth analysis of all dimensions of learning and teaching, and with different conceptual frameworks it proposes, proposes a new perspective on the pedagogy debates, particularly on the construction of the teaching process. As can be seen from the questions asked during the didactic process, it reflects a viewpoint that is grounded more in the idealist philosophy conceptualizing pedagogy as a human science, rather than driven by questions posed by the positivist or experimental perspectives. What does it mean to be a child? What is the difference between a child and an adult? What are the dimensions and meaning of the relationship between the child and the educator? What are the educational objectives? What are the general characteristics of educational outcomes? What are the socio-pedagogical aspects of these characteristics? How can these educational objectives gain legitimacy? What does the thing that we want children to become in the future mean for the children? What are the differences between educating and teaching a child? (Danner, 1994). These are the questions asked by Didactic in general, thinking that the nature of the interaction with the students in the school and the classroom environment can be determined more clearly. Klafki (1995) tackles these questions in a different dimension, stressing the need for a profound didactic analysis of the learning and teaching process. According to Klafki (1995), the questions that need to be asked in the didactic process are as follows: (1) How much does the content presented to the student in the teaching process open up a broad or general understanding of reality? (2) In the minds of children in my class, what is the significance of this course content regarding the experience, knowledge, ability or skill already available to them? (3) What is the 
significance of the subject for the future of the child? (4) How is the content structured? (5) How much of the content determined by these questions should be permanent (minimum information) to qualify as acquired knowledge? This didactic model, as proposed by Klafki (2000), was criticized by student movements that emerged towards the end of the 60 'sfor being too rigid and conservative. Klafki then revised this model to construct a critical constructivist didactic model. Rather than being technical, this model is more sociopedagogically oriented. Influenced by the critical theory of the Frankfurt School, which served as the most important social research center of the period, Klafki succeeded in creating a new perspective within the humanist pedagogy. This new didactic perspective consists of two main dimensions. The first dimension relates to teaching and learning [objectives, content, methods, and forms of regulation], and the second dimension includes school-related social processes and social conditions (Klafki, 1998).

Conditional analysis

Analysis of the concrete, problem-oriented, and socio-cultural background of the learner(s), the teacher(s), and the instution(s).

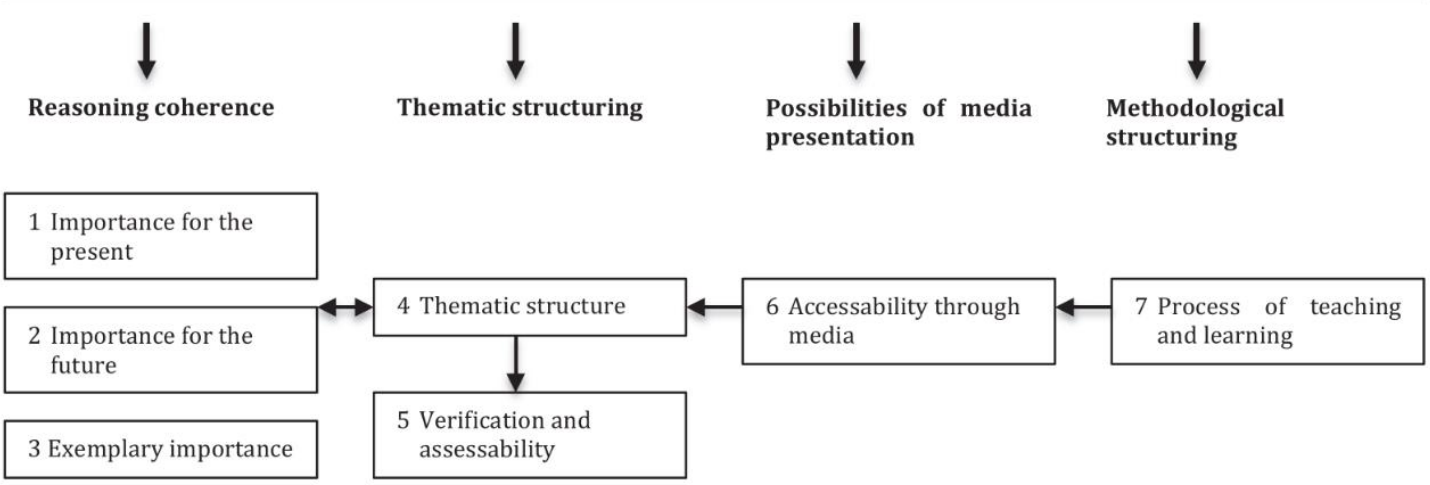

Figure 1. Klafki's Critical Constructivist Didactic Model

Source: Zierer, K. \& Seel, N.M. (2012). General Didactics and Instructional Design: Eyes like twins, A transatlantic dialogue about similarities and differences, about the past and the future of two sciences of learning and teaching, p.7.

Although there are different didactic perspectives in German-speaking countries and Scandinavian countries, this study highlights the main problems of the didactic approach that developed from the humanist pedagogy. When the development of the pedagogy in the US is examined, it is clear that the tradition of German pedagogy, and especially the Herbartian school, played an influential role in American pedagogy for a certain period of time. Despite this effect, a combination of factors such as the rapid development of experimental and educational psychology in the US, the development of the field of curriculum in 1918 with the publications of Franklin Bobbitt, and the Taylorist management approaches caused the Herbartian tradition to weaken towards the mid-1920s in the US. Particularly by the end of the 1800's, graduates from large and well-established universities in Germany (such as Halle, Leipzig, Jena) where about fifty American educators received their PhDs had now lost their influence and began to keep a low-key profile. This period was no longer the age of philosophy or history, but rather the age of an educational science that operated according to the rules of natural sciences, a fact that was summarized well by the American educational historian Ellen $\mathrm{C}$. Lagemann: "You cannot understand the history of American education without accepting that John Dewey lost in the 20th century and that Edward L. Thorndike won" (Lagemann, 1989, p. 185). Thorndike's win was also the victory of the technical scientific paradigm in the field of curriculum studies, required by the Zeitgeist of the period as well. The Eight Year Study is, from this point of view, an important milestone in addressing the issues of curriculum and instruction in a serious way. Only ten years later, Ralph W. Tyler, Hilda Taba, Benjamin Bloom, who are the authors of the world's most influential books in the field of curriculum, actively participated in this project. Tyler proposed the program development model with the experience he gained from this study. Tyler's curriculum development model is completely school-focused. This model, which clearly reflects the technical scientific and linear dimension, addresses learning and education in the context of behavioral change and assigns a critical role to educational psychology in determining objectives. Although this model also includes educational philosophy, the task of philosophy is only determining the consistency and importance of the objectives. In his book titled Basic Principles of Curriculum and Instruction, Tyler (1949) asks the following questions about curriculum development: (1) What are the educational objectives that the school wants to achieve? (2) What learning experiences are needed to achieve these objectives? (3) How can these 
learning experiences be organized effectively? (4) How do we determine if these objectives have been achieved? (Tyler, 1949, p.2). A closer look into Tyler's questions reveals that these questions are appropriate for measurement by their nature, and that they require technical expertise. In the period following Tyler, especially the studies conducted on instructional design in the US have almost always based their models on the Tyler Rationale. The basic aim of the instructional design models is sequencing the teaching process in a logical-analytical way to ensure effective learning. Thus, each step of the teaching process can be designed in a linear and related manner, just like an engineering project which means less philosophy, but more educational psychology and instructional design.

Hopmann and Riquarts (1995) investigate the difference between curriculum and didactic in three levels as lesson planning, research process and theory. The questions both traditions ask in these levels are important in terms of reflecting the diverging perspectives of the two traditions. During the planning level, the curriculum focuses primarily on the "how," and the didactic on the "what" and "why" questions. The questions in the didactic process are asked according to the nature of the Bildung, so it is always central to the process. Table 1 compares these two traditions.

Table 1.

Comparison of the Didactics and Curriculum Approaches.

\begin{tabular}{|c|c|c|}
\hline Level & Curriculum & Didactics \\
\hline \multicolumn{3}{|l|}{ 1. Lesson Planning } \\
\hline core question & how & what and why \\
\hline content as & object & example \\
\hline aims as & task & goal (direction) \\
\hline lesson plan as & course action & frames of experience \\
\hline teaching as & enactment & licensed \\
\hline \multicolumn{3}{|l|}{ 2. Research } \\
\hline focus & $\begin{array}{l}\text { individual teacher } \\
\text { teacher thinking } \\
\text { (interpretative) }\end{array}$ & $\begin{array}{l}\text { art of teaching, Didactics } \\
\text { analysis (hermeneutic) }\end{array}$ \\
\hline $\begin{array}{l}\text { assessment of } \\
\text { successful teaching }\end{array}$ & $\begin{array}{l}\text { student achievement } \\
\text { (scores \& standing) }\end{array}$ & $\begin{array}{l}\text { professional } \\
\text { appropriateness, } \\
\text { reflection }\end{array}$ \\
\hline \multicolumn{3}{|l|}{ 3. Theory } \\
\hline function & preparation & initiation \\
\hline sequence & $\begin{array}{l}\text { subject matter } \\
\text { comes first }\end{array}$ & Bildung comes first \\
\hline
\end{tabular}

Source: Westbury, I., Hopmann, S., \& Riquarts, K. (2000). Teaching as a reflective practice: The German didaktik tradition. Mahwah, NJ: Lawrence Erlbaum Associates, p.18.

\section{Discussion, Conclusion and Implications}

With its own philosophical foundations and historical trajectory, the didactic tradition developed in continental Europe represents a different pedagogical tradition than the Anglo-American curriculum approach. After reaching a certain level of sophistication with the work of Comenius and Raticus, this pedagogical tradition was then systematized by J.F. Herbart's contributions. However, it was Diltheyan pedagogy that reinterpreted Didactic in a certain philosophical tradition. Arguing that as a branch of human sciences, pedagogy would have problems understanding the human if it acted with a structure like natural sciences, Dilthey approached pedagogy as a science that studied the human within his/her historical, cultural and social context. What pedagogy has to do to progress is to analyze, understand and reinterpret problems from a historical point of view. The foundation of a philosophical pedagogy is a hermeneutical perspective based on understanding. Starting to develop as a humanist pedagogy, this movement made a remarkable progress, especially in Germany, and became increasingly popular at universities. The contribution of the idealist philosophical roots of humanist pedagogy to this progress is undeniable. Based on German romanticism, and the work of philosophers like Fichte, Herder and Humboldt, this pedagogy soon became highly inspiring and 
influential. This movement, which has continued to develop since the beginning of the 20th century, has maintained its influence after both world wars. Didactic, whose main purpose is to realize an effective and efficient teaching process, is clearly distinguished from the American educational science tradition, as it achieves this aim in a philosophical context. Because Bildung, a central concept in the didactic tradition, aims to cultivate individuals who are aware of their own realities and have culturally adapted to their social life, it has had to be philosophical by its own didactic nature. After the Second World War, the influence of Americanization in Europe has manifested itself in the didactic field, and some didactic models have emerged that closely resemble the American educational sciences. However, Wolfgang Klafki, one of the representatives of the humanist pedagogy, developed a new didactic structure by synthesizing the tradition of humanist pedagogy with the critical theory of the Frankfurt School. This point of view stands out with its uniqueness and originality among the other didactic models. The originality of this Klafkian perspective undoubtedly stems from its roots in Dilthey's work. Revising his model to strengthen its social dimension after having been inspired by the Frankfurt School and critical theory towards the end of the 60s, Klafki represents a stronger philosophical and socio-pedagogical stance compared to the other didactic instruction models.

So what can such a point of view contribute to the field of curriculum and instruction in general? The reason for the wide adoption of the Anglo-American curriculum approach discourse, especially in the years following the Second World War, was not only because the US was the dominant power in the global hegemonic order, but also because the American scientific curriculum perspective was problem-solution oriented and the techno-scientific paradigm offered easy and feasible solutions especially for the problems in mass schooling, curriculum, and teaching. This prevalent discourse gained even further popularity with the rise of the US hegemony and the cold war threat. Even in Germany, since the late 60s, the American-centered educational research paradigm has become stronger and didactic models have been developed in accordance with the techno-scientific paradigm. From this point of view, it can be said that the Tyler Rationale was the peak of this ascension process. Despite this rising popularity of the Anglo-American approach, the existence of a crisis in the field of curriculum and instruction was first expressed by Joseph Schwab. With the Tyler Rationale and instructional design models enjoying their golden age, Schwab's criticisms and the structure he suggested were not met with popular approval. However, from the 70s onwards, his arguments provided a substantial basis for the intellectual Neo-Marxist and Re-conceptualizationist pedagogical movements. Schwab suggested a theoretical model that was very similar to the German didactic tradition. Could the didactic based on German humanist pedagogy be a solution for the crisis experienced by the Anglo-American curriculum and instruction field? What was to be placed at the heart of the education process, the objectives, or the human being? Did the Anglo-American curriculum and instruction thought developed in the context of management approaches targeting mass production such as Taylorism and Fordism think philosophically enough on some points regarding the humans? This is exactly the point stressed by Schwab (1969: 1): "The field of curriculum is moribund, unable by its present methods and principles to continue its work and desperately in search of new and more effective principles and methods".

What can the curriculum and instruction studies in Turkey gain from the didactic tradition? Obviously, the techno-scientific curriculum theory in Turkey has a very firm basis. In Turkey, especially from the 1960 onwards, since the structuring of the educational sciences programs in the faculties of education and publication of curriculum research has mostly been performed according to this technical-scientific tradition, and because the postgraduate programs are designed by this perspective, the continental European pedagogical discourses have remained quite weak, silent, and somehow disregarded. The most significant contribution of the humanistic pedagogy is the emphasis it places on the view that education is not to be seen only from a perspective that is dominated by positivism, but on the contrary, from a human-oriented perspective that puts the human in the center of the whole education process. The continental European didactic tradition and humanist pedagogy can also help save the curriculum studies field from being a pure field of engineering by contributing to some comprehensive analyses of the teaching and learning process through its hermeneutic and phenomenological methods. It can also be argued that the semantic web provided by the humanist pedagogical didactic approach regarding the concepts such as learning, teaching, school, and culture, will further enhance the Turkish curriculum studies. Viewing pedagogy not as discrete pieces, but as a whole studying the phenomenon called "human" is perhaps the most important benefit to be gained by the field of curriculum and instruction from the didactic tradition. Another potential benefit is its contribution to the teaching process by analyzing a multitude of factors affecting education through various disciplinary lenses, without limiting it to a simple teaching and learning process. Thanks to Didactic, educational concepts can be approached by not only technical procedures and asking "how" questions, but also asking "why" questions 
focusing on meaning and thus achieving multi-dimensional analyses. Different analyses of the teaching process may help solve the instructional crises experienced. For instance, an alternative explanation might be proposed for the root causes of the low success rates at the PISA exam when they are analyzed in light of teacherstudent relationships rather than purely technical problems. All in all, it could be argued that both the AngloAmerican curriculum and instruction and Didactic come up with different solutions for the same problems by using different methods. Common to both traditions is an effort to make the teaching process effective and efficient. Since the scope of this study is limited to the historical development of Didactic, not all the didactic models are discussed in detail. Further, the dialogue between Didactic and Curriculum is not elaborated on at length. Further studies on various models of Didactic may help bring a wider recognition and deeper appreciation of this lesser-known pedagogical tradition in Turkey. 


\section{TÜRKÇE SÜRÜM}

\section{Giriş}

Türkçe ve İngilizce bağlamlarda kullanımına bakıldığında didaktik kelimesinin anlamı çok olumlu değildir. Öğretmen ve öğrenci arasında belirli bir disipline dayalı etkileşimi ifade eden bu kelime eğitim alan yazınında çoğu kez olumsuz anlamda kullanılmaktadır (Kansanen, 1995; Westbury, 2000). Program ve öğretim alanında egemen olan anlayış doğrultusunda neredeyse tüm kavramların tanımlanmasında Anglo-Amerikan kökenli bir perspektifin egemen olduğu söylenebilir (Pinar, Reynolds, Slattery, \& Taubman, 2008; Tahirsylaj, 2017). Bu bakış açısının yanında özellikle program çalışmalarının uluslararasılaşması bağlamında yeni ve farklı bakış açılarının belirlenmesine yönelik girişimlerin günümüzde oldukça etkin olduğu görülmektedir. Örneğin 1970'li yılların başlarında gelişmeye başlayan yeniden kavramsallaştırmacılık, Neo-Marxist program çözümlemeleri, eleştirel teori, postyapısalcı program düşüncesi bu yeni yaklaşımlara ve perspektiflere örnek olarak verilebilir. Program teorisinde ortaya çıkan yeniden kavramsallaştırmacılık, eleştirel teori ve Neo-Marxizm gibi farklı perspektifler yanında farklı felsefi geleneklerle bağlantılı olarak gelişen program ve öğretim paradigmasını farklı açılardan ele alan yaklaşımlarda özellikle program çalışmalarının uluslararasılaşması sürecinde dikkat çekmiştir. Bu bağlamda Kıta Avrupası'nda ve İskandinav ülkelerinde egemen olan didaktik gelenek, program ve öğretim alanında yeni bir araştırma konusu olarak dikkatli bir şekilde işlenmektedir (Deng, 2015, 2016; Gundem, 2000; Kansanen, 1995; Künzli, 1998, 2013; Kruger, 2008; Westbury, Hopmann \& Riquarts, 2000). Program ve öğretim alanında oldukça dikkat çeken bu kavramın anlamı nedir? Didaktik gerçekten ne anlama gelmektedir ve AngloAmerikan program paradigmasından farkı nedir? Didaktik kelimesinin kökeni ve felsefi bağlamı ele alındığında aslında didaktiğin öğretim sürecine yön veren önemli bir kavramsal yaklaşım olduğu görülmektedir. Kavram incelendiğinde, öğrenme ve öğretme sürecine ilişkin tüm değişkenleri içeren ve formal / informal boyutu da bünyesinde barındıran bir bilim olarak tanımlanabildiği gibi (Dolch, 1965 Akt. Gundem, 2000), yeni yetişen kuşakların eğitim aracılığı ile biçimlendirilmesinde kullanılacak yöntem ve içeriğin seçimi olarak da tanımlanabilmektedir. Kavram ile ilgili bu teknik ve ayrıntılı tanımlar şimdilik bir yana bırakılacak olursa kelimenin kökenleri eski Yunanca'da bulunabilir. Eski Yunanca'da didaskein/didaskio kelimesi öğretmen olmak veya eğitmek anlamlarına gelmektedir (Antel, 1952; Hopmann, 2007). Anlam, özellikle zaman içerisinde daha kapsamlı ve ayrıntılı bir boyut kazanmıştır. Kavramın zaman içerisindeki evrimi incelendiğinde ise Eflatun ve Aristo'dan itibaren gelişen bir anlam boyutu olduğu görülmektedir. Bu anlam yapısı Thomas Aquinas, Saint Victor'lu Hugh, Quintillianus, Comenius ve Racitus tarafından genişletilmiştir. Özellikle Comenius'un kaleme aldığı Didaktika Magna bu konuda Avrupa'da yapılan ilk sistemli incelemedir (Hopmann, 2007). Comenius kendisinden öncekilerden farklı olarak didaktik kavramını öğretim sürecinin aşamalandırılması olarak kavramsallaştırmıştır. Almanya'da Comenius ve Racitus sonrası dönemde Salzmann, Basedow gibi eğitimcilerin katkılarının yanında İsviçreli Pestalozzi'nin yolundan ilerleyen Herbart ve Herbart sonrası pedagojinin didaktiğin gelişimine önemli katkılar sunduğu söylenebilir. Bununla birlikte didaktik perspektifte felsefi bağlamın kurgulanması ve böylece zengin bir felsefi sosyo-pedagojik yönelimin doğuşu Wilhelm Dilthey'in hümanist pedagoji perspektifi ile mümkün olmuştur. Bu çalışmanın teorik bağlamını da yine Dilthey'in hümanist pedagoji [Geistteswisseschaftliche Padagogik] perspektifi oluşturmaktadır. Çalışma, dört ayrı fakat birbiriyle ilişkili bölüm olarak kurgulanmıştır. Birinci bölümde didaktiğin gelişim çizgisi betimlenmiştir. íkinci bölümde Herbart pedagojisinin didaktiğe katkıları irdelenmiştir. Üçüncü bölüm Dilthey'ci gelenek bağlamında "Bildung" kavramı ve didaktik perspektife dönük katkıları işlenmiş ve dördüncü bölümde ise Anglo-Amerikan program ve öğretim perspektifi ile didaktik süreç karşılaştırılmıştır.

\section{Türkiye'de Didaktik Üzerine Çalışmalar}

Türkiye'de didaktik konusuna ilişkin çalışmalar büyük oranda öğretmen eğitimi ve öğretim süreci odaklıdır. Bir diğer ifade ile öğretmen eğitiminin alan eğitimi boyutu ile herhangi bir akademik alanın öğretimine ilişkin yaklaşımlar bağlamında ele alınmıştır. Didaktiğe öğretmen eğitimi bağlamında değinen çalışmalar içinde Baki (2010) didaktiği alan öğretimine ilişkin yeterlilikler bağlamında ele alır. Çalışmada didaktiğin alan öğretimindeki önemine dikkat çekilirken öğretmen eğitimi ile alan öğretimi arasındaki ilişkiye dikkat çekilmiştir. Bununla beraber çalışma da herhangi bir tarihsel-felsefi analiz yer almamakta ve salt alan öğretimi bağlamı kullanılmıştır. Yıldırım ve Vural (2014) yaptıkları çalışmada öğretmen yetiştirme ve pedagojik formasyon sorunu üzerinde durmuşlardır. Çalışmada didaktik sadece bir yerde geçmektedir. "Öğretmen Yetiştirmede Finlandiya Modeli" başlığı altında yazarlar Finli öğretmenlerin meslek öncesi eğitimde aldıkları bir ders olarak didaktikten söz etmişlerdir. Bu çalışmada da didaktiğin tarihsel-sosyal ve felsefi bağlamda ne olduğuna değinilmemiştir. Gök ve 
Erdoğan (2017) yaptıkları çalışmada genel didaktikten ziyade alan öğretimi alanındaki didaktik eğilimlerden biri olan didaktik durumlar teorisini matematik öğretimi alanına uyarlamışlardır. Didaktiğin iki ana boyutundan biri olan alan didaktiği herhangi bir akademik alanın öğretimine ilişkin farklı yaklaşımları irdeleyen bir çalışma alanıdır. Bu çalışmada da didaktiğin felsefi ve tarihsel gelişim sürecine değinilmemiştir. Didaktik durumlar teorisine ilişkin bir diğer benzer çalışmada Baştürk Şahin, Şahin ve Tapan Broutin (2017) tarafından yapılmıştır. Bu çalışmada da yazarlar didaktiği yalnızca alan (matematik) öğretimine ilişkin bir yaklaşım olarak ele almış fakat didaktiğin gelişim sürecine veya tarihi arka planına değinmemişlerdir. Yurdatapan ve Şahin (2012) tarafından yapılan çalışmada öğretmen bilgilerinin değerlendirilmesinde "didaktiksel dönüşüm teorisi" kullanılmış, özellikle Fransız didaktik geleneğinde etkin bir akım olan transpoze didaktik yaklaşımının yine alan öğretimine ilişkin yansımaları üzerinde durulmuştur. Türkiye'de didaktik ile ilgili çalışmalar genel olarak değerlendirildiğinde, didaktiğin daha çok alan öğretimi veya alan bilgisi bağlamında ele alındığı fakat didaktiğin aslında ne olduğuna ilişkin herhangi bir kavramsal çerçevenin çalışmalarda yer almadığı görülmektedir. Dolayısıyla yapılan bu çalışma ile Türkçe alanyazındaki bir boşluğun doldurulacağı düşünülmektedir.

\section{Yöntem}

Kıta Avrupa'sında didaktiğin gelişimini ve temellerini inceleyen bu çalışma nitel bir araştırmadır. Nitel araştırmalar genelde olgu veya olayların derinlemesine incelemesinde kullanılmaktadır. Çalışma, didaktiğin temellerini ve gelişim çizgisini tarihsel ve felsefi bağlam içinde betimlemeyi amaçlamıştır. Çalışmanın temel veri kaynağı olan konu ile ilgili alan yazın, nitel araştırma yöntemleri içinde yer alan doküman analizi kullanılarak değerlendirilmiştir. Doküman analizi yöntemi, araştırılması hedeflenen olgu veya olgular hakkında bilgi içeren yazılı materyallerden verilerin araştırma amacına uygun biçimde toplanmasını kapsamaktadır (Yııdııım ve Şimşek, 2008). Doküman analizi için araştırma problemleri ile ilgili alanyazın büyük bir önem taşımaktadır. Problem cümlesi ve çalışmanın amacı doğrultusunda ilgili alanyazın elde edilmesi doküman analizinde ilk adımdır. Bu çalışmada kullanılan alanyazın içinde yer alan kitaplar olabildiğince orijinal kopyalarına ulaşılarak elde edilmiş, orijinal kopyaları olmayan eserlerin ise araştırma problemine ilişkin belirli bölümleri kullanılmıştır. Makale olarak olabildiğince indeksli dergiler tercih edilse de web sayfalarından da yararlanılmıştır. Makale taramalarında anahtar kelimelerden yararlanılarak konu ile ilgili temel kitapların bibliyografyalarında verilen makaleler de üniversite veri tabanlarından elde edilmiştir. Araştırma sürecinde, araştırmanın problemleri bağlamında alan yazın taraması yapılmış ve gerekli kaynaklar sınıflandırılmışıı. Her bir kaynak problemler doğrultusunda eleştirel bir şekilde okunmuş ve ilgili probleme göre manüel olarak kodlanmıştır. Yapılan kodlamaya göre ayrılan notlar daha sonra her bir problemi irdelemek amacıyla kullanılmıştır. Döküman analizinde sürecin güvenirliği ve geçerliğini temin için ilk olarak elde edilen alanyazının araştırmanın problemleri ile ilişkili olup olmadığı test edilmiştir. Bu süreçte araştırmacılar ayrı ayrı kaynakları irdelemiş ve kaynakların yeterliliği ile ilgili görüş birliği aranmıştır. Diğer bir önlemde araştırma problemleri ile ortaya konulan kod ve temalar üzerinde görüş birliğinin aranmasıdır. Okunan kaynaklardan elde edilen notların problemler ile ne derece ilişkili olduğu konusunda da görüş birliği aranmıştır. Araştırmanın dört temel problemi vardır. (1) Didaktiğin tarihsel süreklilik içindeki gelişimi nasıl bir seyir izlemiştir? (2) Herbartçı pedagojinin didaktiğe olan katkıları nelerdir? (3) Hümanist pedagojinin didaktik ile olan ilişkileri nasıl bir gelişim göstermiştir? (4) Didaktik gelenek ile Anglo-Amerikan program düşüncesi arasındaki farklılıklar ve benzerlikler nelerdir? Çalışma bu dört soruya cevap verebilecek şekilde kurgulanmıştır.

\section{Didaktiğin Gelişim Çizgisi}

Hopmann (2007) didaktiğin gelişim çizgisini net bir şekilde belirleyen kavramsal bir çerçeve önermiştir. Buna göre didaktiğin tarihsel açıdan gelişim çizgisi üç ana kavram etrafında şekillenmiştir. Bu üç ana kavram, sıralama, aşamalııık ve seçimdir. Didaktiğin gelişim çizgisindeki ilk adım öğretilecek konunun sıralanmasının nasıl belirleneceği sorusu ile ilgilidir. Bir diğer ifade ile konu nasıl bir düzene konulup nasıl bir sıra ile öğrenciye sunulacaktır? Kavramın bu anlamı Eski Yunan'da Eflatun ve Aristoteles'in metinlerinde bulunmaktadır. Meno isimli diyalogda Sokrates bir köleye geometrik bir problemin çözümünü anlatmaktadır. Sokrates ve köle arasındaki diyalogda Sokrates'in tek yaptığı anlamlı, belli bir sıra içerisinde ilerleyen sorular sormaktır. Her bir soruya verilen yanıt arkasından başka bir soruyu getirmektedir. Sokrates'in burada vurguladığı nokta her ne kadar idealist felsefenin epistemolojisini gösterse de aslında öğretim süreci hakkında temel boyutları vurgulamaktadır (Jarvis, 2006). Sokrat'ın perspektifinde didaktiğe bakıldığında öğretmenin temel görevi içerik ile öğrenen arasında gerçekleşen etkileşimi kolaylaştıran ve etkileşimi başlatan olmasıdır. Iç̧eriğin anlam kazanması öğretmenin süreç içerisinde sorduğu sorularla mümkün olmaktadır. Didaktiğin kökenlerinin Eski 
Yunan medeniyetinde saklı olduğu daha önce vurgulanmıştı. Bu saklı perspektif nasıl oldu da Avrupa'ya aktarıldı ve bir öğretim geleneğinin oluşum süreci başladı?

Eski Yunan medeniyetinin mirası İslam dünyası tarafından Avrupa'ya aktarılmıştır (Gutas, 1999; Hodgson, 1974; Makdisi, 1981). Bu aktarım sürecinde Avrupa hem eski Yunan klasiklerini tanımış fakat daha da önemlisi Arap-Endülüs kültürel katkısını da öğrenme imkânı bulmuştur. Bu miras Avrupa'nın ortaçağ denilen dönemden çıkışında önemli bir etki yapmıştır (Saliba, 2007). Doğal olarak İslam medeniyetinin öğrenme ve öğretime ilişkin bakış açısı da Avrupalı düşünürleri etkilemiştir. Bu süreç içinde ortaçağın önemli filozoflarının öğretim sürecine ilişkin perspektiflerini görmek mümkündür. Bir diğer ifade ile didaktik konusu ortaçağda Avrupa filozoflarının problemi haline gelmiştir. Manastırlarda Dominikçi ve Fransisçi ekollere ilişkin dersler veren bu filozoflar için didaktik zor ve muğlak konuların anlaşılması için bir anahtar rolü oynamıştır. Bu filozoflardan biri olan Saint Victor'lu Hugh didaktik konusunda ilk tetkiklerden birine imza atmıştır. Hugh, öğretim sürecini disiplinli bir eylem olarak nitelemekte ve öğrenmenin ancak disiplinli bir çevre ve disiplinli bir süreç neticesinde gerçekleşeceğini vurgulamaktadır (Hopmann, 2007; Roest, 2000; Rorem, 2009). Bir diğer Katolik filozof Thomas Aquinas da yıllar sonra Hugh'un düşüncelerini daha farklı bir boyuta taşımıştır. Summa Theologica isimli eserinde öğrenme sürecinde öğrencinin faaliyetini önemsemiş ve öğretmeni bu süreç içinde öğrenciye yardım eden olarak tanımlamıştır (Copleston, 1962; DeWulf, 1959).

Didaktiğin gelişim çizgisinde ikinci önemli adım ise aşamalılıktır. Avrupa'da reform çağı olarak anılan dönemde gerçekleşmiştir. Rönesans sonrası özellikle kilise ile mücadelenin ardından reform çağında meydana gelen gelişmeler didaktiğin anlam olarak yeni bir boyuta taşınmasına neden olmuştur. Katolik kilisesine karşı başlatılan ve kanlı olarak geçen mücadele Protestanlığın yayılması açısından önemli bir kırılma noktası olmuştur. Protestanlığın yayılmasından daha önemli bir gelişme ise eğitim ve sosyal refah alanında başlayan arayıştır (Lindberg, 2010). Bu arayışın en önemli sonucu ise öğretim sürecinin niteliğine iliş̧kin girişilen tartışmalardır. Reform çağının didaktik düşüncesine en önemli katkıyı sunan düşünürü ise kuşkusuz Comenius'tur. 1592-1670 yılları arasında yaşayan Çekya'lı Protestan papaz belki de pedagoji ve didaktik tarihinde silinmez bir iz bırakmış büyük düşünürler arasında yer almaktadır. Avrupa'da reform çağı bütün hızı ile sürerken yaşama başlayan Comenius için okullar toplumun mutluluğu ve Hristiyanlığın gelişmesi için hayati derecede önemliydi. Toplumsal gelişme düşüncesinin kaynağını eğitimde gören Comenius için en önemli sorun mevcut okullarda verilen verimsiz ve işe yaramayan eğitimdi. Bu işe yaramaz eğitimin en önemli açmazı öğretim yöntemleriydi. Eğer yöntemlerde bir reform gerçekleşebilirse okullar aydınlığın yayıldığı yerler olabilirdi. Bu sorunların çözümünde ilk adım olarak bir ders kitabı yazmıştır. Orbis Sensualium Pictus adını taşıyan bu eserde didaktiğin temellerini bulmak mümkündür. Comenius, küçük ve kısa hikâyeler ile aşamalı bir şekilde küçük çocuklara dünyayı tanıtmaktadır. Daha sonra kaleme alınan Didactica Magna ise öğretimde bugün bile kullanılan yakından uzağa, bilinenden bilinmeyene ilkelerinin açıklandığı didaktiğin temel ilkelerini açıklayan öncü kitaplardan biridir (Leek, 2011; Lukaš \& Munjiza, 2014). Comenius, kendi didaktik sistemini üç Latince kavramın birbiri ile ilişkisi bağlamında tanımlar: Omnes, omnia ve omnino (Siljander \& Sutinen, 2012). Omnes [Herkes] kavram olarak okul sistemine işaret eder. Herkes için çocukluktan başlayarak kademeli bir eğitim sistemi tasarlanmalıdır. Dolayısıyla Omnes eğitilecek birey anlamına gelir. Omnia [her şey veya her türlü bilgi] bilgidir. Bireylerin aydınlığa çıkması ancak onların bilgi sahibi olması ile mümkündür. Omnino [Bütün duyularla] ise yönteme karşılık gelir (Gundem, 1992; Menck, 2014). Böylece didaktiğin temeli öğretmen ile öğrenci arasında bilgi vasıtası ile kurulan ilişkidir. Bu ilişkide Comenius, aşamalılığı anahtar bir kavram olarak görür. Öğrenciye sunulacak bilgi küçük parçalar halinde ve aşamalı olarak sunulması Comenius didaktiğinin esasıdır. Comenius için didaktiğin temel amaçları şunlardır:

Didaktiğimizin temel amacı şunlar olmalıdır: öğretmenlerin daha az öğrettiği fakat öğrencilerin daha çok öğrendiği bir öğretim metodunu aramak ve bulmak, okulları gürültünün, isteksizliğin ve israf edilen emeğin değil fakat daha fazla hoş vakit geçirilen ve kesin bir gelişmenin olduğu ortamlar haline getirmek. Böylece Hristiyan topluluğunun karanlıktan, kafa karışıklığından ve fitneden kurtularak aydınlığa, huzura ve düzene ulaşmasıdır (Comenius, 1907, p.5).

Didaktiğin gelişim çizgisinde üçüncü adım ise seçimdir. Didaktik, öğrenciye ne öğretileceğinin de esasını teşkil etmektedir. Didaktiğin bu anlam çerçevesini kazanması 18. yüzyılın sonu ile 19. yüzyılın başlarında gerçekleşmiştir. Tüm Avrupayı etkileyen Yedi Yıl Savaşları, arkasından gelen Fransız Devrimi ve takip eden yıllarda Napolyon savaşları ile Avrupa'da ortaya çıkan kargaşa ile mücadelede yeni yetişen kuşaklara nelerin öğretilmesi gerektiği sorusunun tartışılmasına neden olmuştur. Comenius'un ifade ettiği her şeyi herkese öğretmek yerine işe yarar bilgiyi öğretme düşüncesi didaktiğin anlamının genişlemesini sağlamıştır. Bu fikri ilk keşfeden ve uygulayanlar Prusyalılardır. Prusya devletinde eğitim bürokrasisi oluşturulurken öğretmenlerin dersleri nasıl verecekleri ve konuları seçerken nelere dikkat etmeleri gerektiğine ilişkin önemli düzenlemeler 
yapılmıştır (Blackbourn, 1998; Levinger, 2000). Hopmann (2007) Prusya eğitim bürokrasisinin bu düzenlemeleri ile devlet tarafından yazılı ve resmi olarak ilk eğitim programının ortaya çıktığını vurgular. Bu konuda Goodson (2004) ve Westbury vd. (2016) aynı görüşü paylaşır ve Prusya'nın Waterloo Savaşının hemen ertesinde 1816 yılında uygulamaya koyduğu planı [Normalplan für Gymnasien] devletin eğitimi sosyal bir ürün haline getirmek amacı ile yaptığı kapsamlı bir uygulama olarak değerlendirir. Bu plan ile devlet eli ile okul kademelerine uygun eğitim programları hazırlanmış, ders kitapları basılmış, okullar için zaman tabloları düzenlenmiş, verilecek ödüller ve sınavlar ile ilgili kapsamlı düzenlemeler yapılmıştır. Böylece didaktiğin temel anlamları içine bilginin seçimi de girmiştir. Bu aslında Anglo-Sakson dünyasında Herbert Spencer tarafından dile getirilen en değerli bilgi nedir [What knowledge is of most worth?] sorusunun kıta Avrupa'sında sorulmasından başka bir şey değildir. Eğitimin sosyal bir ürün haline gelmesi ve yeni yetişen kuşakların belirli bir kültürel formasyona (biçimlendirmeye) tabi tutularak yeniden inşa edilmesi Kıta Avrupa'sında ilk defa Almanya'da gerçekleşmiştir. Böyle bir formasyon sürecinin etkili ve verimli olması ise belirli bir sistem ve yapı problemidir. Didaktik bu aşamada devreye girmekte ve okullar ile ilgili yapılacak tüm eylemlerin odak noktasında yer almaktadır. Didaktiğin temel işlevi, okulların bireylere vereceği kültürel, zihinsel ve ruhsal anlamda biçimlendirme görevinin etkili bir şekilde icrasıdır. Ama bu icranın gerçekleşmesinden önce bu kültürel biçimlenmenin felsefi bağlamda tahlili gerekmektedir. İşte burada devreye Bildung kavramı girmektedir. Kavram İngilizceye basit bir şekilde "education," Türkçe'ye ise terbiye / eğitim olarak çevrilse de asıl anlamı oldukça derin ve felsefidir. 20. yüzyılın önde gelen pedagoglarından Eduard Spranger, Bildung kavramını şu şekilde tanımlamıştır:

Bildung, kültürel etkilerle elde edilen ve homojen, yapılandırılmış ve geliştirilmeye uygun olan bireyin özünün oluşumudur; özünün bu oluşumu, bireyi nesnel olarak değerli kültürel başarılara götürür ve nesnel kültürel değerleri deneyimlemesine (kavramasına) olanak tanır. Geçici özelliklere dayanmadığı için Bildung esasen bireyin özünün oluşumudur. Bildung homojen ve yapılandırılmış, yani kapsamlı ve çok katmanlı bir süreçtir. Sadece tek boyutlu ruhsal kültürü olan kişiye "gebildet" (eğitimli) denemeyeceği gibi çok boyutlu fakat merkezi bir odak noktasından veya sağlam bir özden yoksun, dağınık ve biçimsiz bir bireye de eğitimli denemez. Gerçek anlamda Bildung, her zaman gelişimsel eğilimler ve sürekli büyümeyi kapsar, çünkü Bildung gelişim sürecinin rafine bir sonucundan başka bir şey değildir. Bu rafine sonuç ise bireye etki eden kültürel etmenler (toplumun benimsediği değerler silsilesi) ile mümkün olabilir. Bu değerler silsilesi hem bireyin içinde bulunduğu toplumun kültürel değerlerini anlamasını hem de kendi kültürel dünyasını yeniden şekillendirmesini sağlar. Kültürel etkiler, nesnel bir değer içeriğini temsil eder. Bunlar bir yandan kişinin kültürel içerikleri anlamasını sağlarken diğer yandan da kişinin ruhunda kendini anlamaya ve deneyimlerini nesnel kültürel değerlere (kazanımlara) dönüştürmeye yönelik değer üretici güçleri uyandırır. Bu deneyimler ve güçler için kişisel bir merkezin de bulunması gerekir. Kültürel değerleri homojen bir şekilde bu merkezle ilişkilendirerek, ham bireysellik tam eğitimli (gebildete) kişiliğe yükselir (Spranger, 1968, pp.24-26).

Didaktiğin, Kıta Avrupa'sındaki gelişim çizgisinde Bildung kavramı ile buluşması oldukça önemlidir. Alman pedagojisinin kültürel bağlamında üretilen bir kavram olarak Bildung, didaktik perspektifini farklı bir boyuta getirmiştir. Bu aşamada özellikle Comenius ve Wolfgang Ratke'nin Alman didaktik geleneğinin inşasındaki rolleri büyüktür. Her ikisinin de ortak amacı öğretim sürecinin etkili ve verimli bir şekilde nasıl inşa edileceğine ilişkin bir yol bulmaktır (Kansanen, 1995). Almanya'da Ratke'nin öncülüğünde gelişen didaktik perspektif zaman içerisinde Bildung kavramı doğrultusunda yeni bir anlam kazanmaya başlamıştır. Özellikle Alman felsefesinin idealist karakterinin yön verdiği bu hareket aynı zamanda hem zengin bir pedagojik birikimin oluşmasına neden olmuş hem de didaktiğin farklı boyutlarda gelişmesini sağlamıştır. Bu gelişim sürecinde özellikle 18. yüzyılın sonu ile 19. yüzyıl önemli gelişmelere sahne olmuştur. Didaktiğin insan bilimleri veya hümanist pedagojinin bir parçası olma sürecinde bu dönem önem taşımaktadır. Bu süreç içinde ilk incelenmesi gereken Johann Fredrich Herbart ve takipçileri tarafından sistematik hale getirilen Herbart'çı didaktiktir.

\section{Herbart ve Herbart'çı Didaktik}

Johann Fredrich Herbart (1776-1841) pedagoji tarihinde didaktik açısından önemli bir miras bırakmış, görüşleri ile Amerikan pedagojisinin gelişimine katkı sağlamış, sistemli ve doktriner bir filozoftur (Hilgenheger, 1993; Gutek, 2013). Herbart'ın en önemli katkısı Locke'dan itibaren bilimsel esaslara dayalı olarak, çalışılan pedagojinin bilimsel, sistematik bir yapıya kavuşmasına dönük yaptığı çalışmalardır. Diğer bir ifade ile bilimsel pedagojinin oluşmasında öncü rol oynamıştır. Herbart için bilimselden kasıt akıl, mantık ve felsefe bağlamında oluşan bir sistem anlamındadır. Bilim burada pozitivist bir anlam içinde değil idealist bir felsefi bağlam içinde kullanılan bir ifadedir. Herbart'ın didaktik alanına katkısı kuşkusuz Bildung kavramının didaktik ile birleştirilmesi ve eğitici öğretim adı verilen bir yaklaşımın teorisini kurgulamasıdır. Didaktiğin temel gayesi öğretim sürecinin akılcı ve mantıklı bir düzen, sıra ve aşamalılık içinde öğrenciye sunulmasıdır. Bu eğitici -Bildung- süreci yalnızca 
belirli teknik adımlarla değil aynı zamanda kapsamlı bir yapı içinde mümkündür. Yani didaktik, Bildung'u gerçekleştirmek için bazı anahtar niteliğinde değişkenlerle beraber irdelenmelidir. Egemen (1965) bu üç anahtar değişkeni idare, öğretim ve disiplin olarak tanımlar. İdarenin anlamı çocuğun okul ortamında her türlü zararlı etkiden korunması, söz dinlemesi, çocuğun belli bir düzene alıştırılmasıdır. Öğretim ise çocuğun ahlaklı, bilgili ve becerikli olmasına ilişkin her türlü eylemdir. Herbart'ta öğretimin gayesi çocuğu terbiye -bildungetmektir. Terbiye etmeyen, çocuğa belli alışkanlıkları kazandırmayan, onun sosyal çevreye uyumunu sağlayamayan ve sadece kuru bilgiler veren bir öğretim, öğretim değildir. Disiplin ise bireyin bu süreçlerinin belli bir sistem içinde gerçekleşmesidir. Dolayısıyla sistem olmaksızın herhangi bir biçimlendirmeden söz etmek mümkün değildir.

Herbart'ın ileri sürdüğü bu doktrinin bir başka yönü de kuşkusuz didaktik boyutuna getirdiği sistemdir. Formal Basamaklar olarak anılan bu teoride Herbart, bildung gayesine hizmet edecek didaktik bir çerçeve sunar. Buna göre bir dersin eğitici olabilmesi için (1) Hazırlık, (2) Sunum, (3) iliş̧kilendirme, (4) Sistematizasyon ve (5) Uygulama gereklidir (Herbart, 1904, p.59). Herbart'ın didaktik sürece ilişkin sunduğu bu basamaklar hem öğretimi daha etkili hale getirecek hem de Comenius'tan beri ileri sürülen verimliliği getirecektir. Bununla beraber Herbart didaktiği, özellikle öğretim sürecini mekanik bir boyuta hapsettiği ve yaratıcılığı engellediği noktasında eleştirilse bile o güne kadar yapılmayanı yapmış ve didaktiği bir yöntembilim haline getirmiştir. Herbart sonrası dönemde özellikle takipçileri olan Tuiskon Ziller, Wilhelm Rein, Ludwig Strümpell, Herbartçı didaktik teorinin gelişimine katkı sağlamışlardır. Bununla beraber özellikle 20. yüzyılın başlarından itibaren iş Okulu [Arbeitschule] karşısında değerini kaybetse de hümanist pedagojinin elinde yeniden hak ettiği yeri almıştır. Herbart'ın belirli bir teknik süreç olarak ele aldığı didaktiğe hümanist pedagoji daha derin felsefi bir boyut kazandırmıştır. Bu felsefi boyut ilk olarak eğitime ilişkin tüm kavramların etkili bir şekilde ve derinlemesine tartışılmasına katkı sağladığı gibi farklı didaktik perspektiflerin de gelişmesine zemin hazırlamıştır. 20. yüzyılın en etkili didaktik teorisyenlerinden olan Wolfgang Klafki, Eric Weniger bu sürecin mimarları arasındadır. Wilhelm Dilthey ve onun insani bilimler yaklaşımı ise yeni bir pedagojik gelenek olan hümanist pedagojinin doğuşunu sağlamıştır.

\section{Hümanist Pedagoji ve Didaktik}

Didaktik anlayışın gelişim çizgisinin belki de en önemli boyutu, onun Alman pedagojisinin içine girişi olmuştur. Gerçekten de pedagoji tarihi eleştirel bir şekilde incelendiğinde eğitimin felsefeden ayrı bir bilim olarak gelişiminde Alman pedagojisinin farklı bir mecrada ilerlemiş olduğu net bir şekilde görülebilir. Bir diğer önemli boyut, Alman pedagojisinin bu gelişim çizgisinin daha sonraki dönemlerinde Amerikan pedagojisinde de 1875-1925 yılları arasında etkili bir pedagojik söylemin temeli olmasıdır (Gutek, 2013; McNeil, 2015; Ohles, 1978). Hümanist eğitim biliminin gelişimi didaktiğin temellerini anlamak için önemlidir, zira 20. yüzyılda farklı ekollere bölünmüş olsa bile pedagojik gelenek içinde didaktiğin Bildung kavramı ile en zengin etkileşimi hümanist pedagoji ile mümkün olmuştur.

Hümanist pedagoji her ne kadar felsefi anlamda derin köklere sahipse de gelişimi 1910-1920 arası dönemde gerçekleşmiştir. Friedrich Schleiermacher (1768-1864) ve Wilhelm Dilthey (1833-1911) in felsefi tarihsel çalışmaları üzerine temellenen hümanist pedagoji bu dönemde sistematik bir yapı halinde kurgulanmıştır. Dolayısıyla sistematik hale getirilmesi 20. yüzyılın başlarında olsa da 19. yüzyılda Almanya'da egemen olan pedagojik bir anlayıştır. Oldukça önemli bir geleneğin oluşmasına katkı sağlayan hümanist pedagoji, didaktik gelenek içerisinde de zengin bir perspektifin oluşmasına katkı sunmuştur. Herman Nohl, Theodor Litt, Eduard Spranger, Wilhelm Flitner ve Erich Weniger bu ekolün yetiştirdiği önemli pedagog ve didaktikçilerdir. Yine bu okul içinde farklı bir kol olarak gelişen Göttingen Okulu bünyesinde yetişen Nohl ve Weniger'in takipçileri Wolfgang Klafki ve Klaus Mollenhauer günümüzde didaktik denildiğinde ilk akla gelen isimler arasındadır (Biesta, 2013; Van Manen, 2015; Wulf, 2014). Tröhler (2003) hümanistik pedagoji [Geisteswissenschaftliche Padagogik] nin gelişim sürecini kurumsal yazın ve bilimsel yayıncılık gibi belirli bazı etkenlere dayalı olarak açıklar. Bu etkenler içinde en güçlü olan damar Alman felsefi geleneğinde idealist felsefenin merkezi bir noktada olmasıdır. İdealist felsefenin Alman edebiyatını şekillendirmesi ve insanı ruhsal bir varlık olarak ele alma düşüncesi hümanist pedagojinin gelişim çizgisinde önemli bir yer tutar. Bu geleneğin gelişimi özellikle Wilhelm Dilthey'in kavramsallaştırması ile yeni bir boyuta ulaşmıştır. Dolayısıyla hümanist pedagoji ve didaktiğin merkezinde Dilthey'in yorumları yer alır denilebilir. Dilthey, idealist felsefeyi tarih ve insan merkezli bir bakış açısıyla yeniden yorumlamıştır. İnsan Dilthey'e göre tarihsel, sosyal ve kültürel bir varlıktır. Bu nedenden dolayı insanı anlamak ancak tarihsel, sosyal ve kültürel bir bağlamda gerçekleşebilir. İnsanı insan yapan temel özellik onun tarihsel bir varlık olmasıdır. İnsanın ortaya koyduğu tüm artefaktalar [yapay olgular] yani dil, sanat, felsefe, hukuk, edebiyat ve eğitim ancak kendi tarihsel zaman dilimi ve tarihsel kimliği ile belirli 
bir sosyo-kültürel bağlam içinde anlam kazanır (Bulhof, 1980). Bu anlam dünyasında eğitim ve eğitime ilişkin kavramlar da vardır. Pedagoji doğrudan doğruya insanı - acıları, dertleri, kederleri ve sevinçleri ile - konu ettiği için insani bilimler içinde önemli bir yere sahiptir. Bundan dolayı pedagoji Dilthey için bir doğa bilimi değil insani bir bilimdir. Bu perspektifi ile klasik pozitivist insan ve bilim kavramına da açıkça tepki gösterir ve cephe alır. Dilthey için pedagojinin görevi herhangi bir zaman diliminde ortaya çıkan tarihsel toplumsal gerçekliğin ne kadar homojen bir yapı içinde oluştuğu, bu yapıyı etkileyen unsurların yapısını ve bu homojen yapının oluşumuna olan katkılarını teşhis etmek ve gelişimini yöneten etkenleri tanımlayarak bu sosyal tarihsel gerçekliğin özgün boyutlarını keşfetmektir. İnsanın doğasının anlaşılması ancak böyle mümkün olabilir ve insanı etkileyen tüm artefaktaların insan üzerinde tesiri de ancak böyle çözümlenebilir. Bu durum sınıfta öğrenci ve öğretmen ilişkisi bağlamını inceleyebileceği gibi, didaktik sürecin gerçekleşmesine etki eden unsurların da çözümlenmesini sağlar. Didaktiğin en önemli konuları arasında yer alan öğretilecek içeriğin seçimi, içeriğin sistematikleştirilmesi ve bunun öğrenci ile etkileşim sürecine konularak öğrenilmesi de insan bilimleri pedagojisinin üzerinde önemle durduğu bir problemdir. Okullarda yapılan öğretim sürecini yönlendiren eğitim programları ve ders kitapları yetişkinler tarafından belirli ideolojik ve etik eğilimler bağlamında hazırlanmaktadır. Okullar bu sayede geleceğin yurttaşlarını yetiştirmektedirler. Bu sürecin çözümlenmesi ve didaktik sürecin öğrenen, içerik ve öğretmen bağlamında analizi felsefi bir bağlam içinde yapılmalıdır. Burada kullanılan bu yöntem ise hermenötiktir. Böylece insani bilimler pedagojisi hermenötiği kendisi için temel bir yöntem olarak kabul etmektedir. Hümanist pedagoji didaktik dâhil olmak üzere tüm kavramlarını bu hermenötik perspektif ile tanımlamaktadır. Bu gelenek içinde önemli bir yeri olan Herman Nohl'un eğitim tanımı da yine bu perspektif doğrultusundadır. Nohl'a (1949) göre eğitim bir yetişkin ile kendi yaşamını idrak eden ve şekillendiren, gelişmekte olan bir varlık arasındaki ilişkidir. Eğitimi bu şekilde tanımladıktan sonra didaktik perspektif daha bir netlik kazanır. Nohl (1949) eğitim tanımı ile farklı bir felsefi dünyaya olan aidiyetini göstermektedir. Bununla beraber bir başka ve farklı felsefi dünya da Anglo-Amerikan eğitim programı ve öğretim alanında mevcuttur. Bu iki gelenek farklı sorular ile benzer problemleri çözmeye çalışmaktadır.

\section{Eğitim Programı ve Didaktik: Farklı Sorular ile Aynı Olgular}

Didaktik, temel problem olarak öğrenme ve öğretim sürecinin doğasını anlamaya yönelik felsefi boyutu ağır basan fakat aynı zamanda sosyo-pedagojik bir perspektifi de içinde bulunduran süreçleri inceleyen bir alandır. Sadece öğretim sürecinin teknik analizi ile yetinmeden öğrenme ve öğretimin tüm boyutları ile derinlemesine tahlil edilmesini savunan bu yaklaşım ileri sürdüğü farklı kavramsal çerçeveler ile pedagoji tartışmalarına ve özellikle öğretim sürecinin inşasına yönelik yeni bir bakış açısı önermektedir. Didaktik süreç içinde sorulan sorulara bakıldığında görüleceği gibi didaktik süreç pozitivist veya deneysel bir bakış açısından cevaplanacak türden sorularla değil, daha fazla idealist felsefe temelinde gelişen ve pedagojiyi insani bir bilim olarak kavramsallaştıran bir bakış açısını yansıtır. Çocuk olmanın anlamı nedir? Bir çocuk ve yetişkin arasındaki fark nedir? Çocuk ve eğitimci arasındaki ilişkinin boyutları ve anlamı nedir? Eğitim amaçları nelerdir? Eğitimle ulaşılmak istenen sonuçların genel özellikleri nelerdir? Bu özelliklerin sosyo-pedagojik açıdan temelleri nedir? Bu eğitim amaçları nasıl meşruiyet kazanabilir? Çocukların gelecekte olmasını istediğimiz şeyin çocuklar için anlamı nedir? Bir çocuğun eğitilmesi ve öğretilmesi arasındaki farklılıklar nelerdir? (Danner, 1994). Bu sorular didaktiğin genel bağlamda sorduğu sorulardır. Böylece okul ve sınıf ortamında yapılacak ve öğrencilerle girilecek etkileşimin doğasının daha net bir şekilde belirlenebileceği düşünülmektedir. Klafki (1995) bu soruları daha farklı bir boyuta taşır. Böylece öğrenme ve öğretim sürecinin derinlikli bir didaktik analizinin yapılabileceğini vurgular. Klafki'ye (1995) göre didaktik süreçte sorulması gereken sorular sırası ile (1) Öğretim sürecinde öğrenciye sunulan içerik ne kadar geniş veya genel bir gerçeklik anlayışını öğrenciye açmaktadır? (2) Sınıfımdaki çocukların zihninde bu söz konusu ders içeriğinin, deneyimin, bilginin, yeteneğin veya becerinin (zaten onlarda mevcut bulunan) önemi nedir? (3) Konunun çocuğun geleceği açısından önemi nedir? (4) İçerik nasıl yapılandırılmıştır? (5) Edinilmiş bilgi olarak nitelendirilebilmesi için bu sorularla belirlenen içeriğin ne kadarı kalıcı olmalıdır (minimum bilgi)? Klafki (2000) tarafından ileri sürülen bu didaktik model 60'lı yılların sonlarına doğru gelişen öğrenci hareketleri tarafından katı ve muhafazakâr olarak eleştirilmiştir. Klafki daha sonra bu modeli revize ederek eleştirel yapılandırmacı bir didaktik model kurgulamıştır. Klafki'nin bu modeli teknik boyutların yanında daha fazla sosyo-pedagojik bir yönelime sahiptir. Döneminin en önemli sosyal araştırmalar merkezi olarak işlev gören Frankfurt Okulu'nun eleştirel teorisinden etkilenen Klafki, hümanist pedagoji içinden yeni bir perspektif oluşturmayı başarmıştır. Bu yeni didaktik perspektif iki ana boyuttan oluşmaktadır. illk boyut öğretim ve okula ilişkindir [hedefler, içerik, yöntem ve düzenleme biçimleri] ikinci boyut ise okul ile ilgili sosyal süreçler ve sosyal koşulları ihtiva etmektedir (Klafki, 1998). 


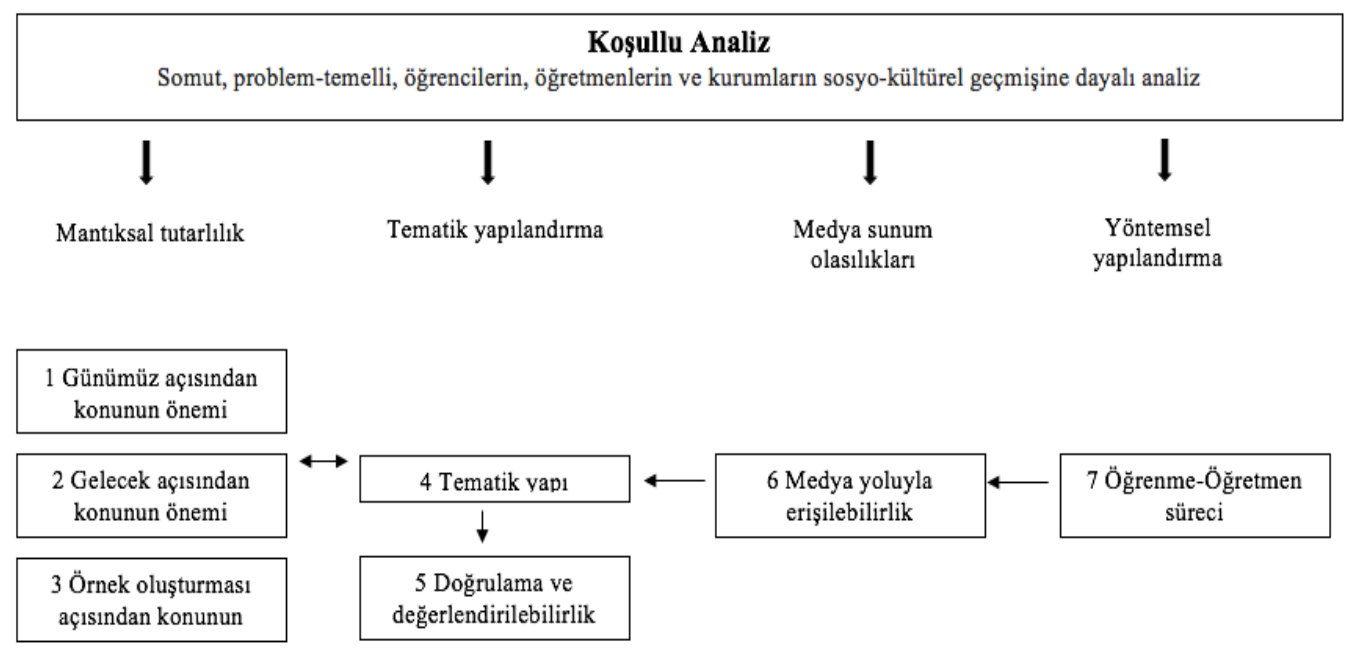

Şekil 1. Klafki'nin Eleştirel Yapılandırmacı Didaktik Modeli.

Kaynak: Zierer, K. \& Seel, N.M. (2012). General Didactics and Instructional Design: Eyes like twins, A transatlantic dialogue about similarities and differences, about the past and the future of two sciences of learning and teaching, p.7.

Kıta Avrupa'sında Almanca konuşulan ülkelerde ve İskandinav ülkelerinde farklı didaktik perspektifler olduğu halde bu çalışmada hümanist pedagojiden gelişen didaktik anlayışının temel problemleri üzerinde durulmuştur. Pedagojinin Amerika'daki gelişim çizgisi incelendiğinde, Alman pedagoji geleneğinin ve özellikle Herbart'çı okulun Amerikan pedagojisinde belli bir dönem etkili bir rol oynadığı açıkça görülmektedir. Bu etkisine karşın Amerika'da deneysel psikoloji ve eğitim psikolojisinin gelişiminin oldukça hızlı olması, eğitim programı alanının 1918 yılında Franklin Bobbitt’in yayınları ile gelişmeye başlaması ve Taylorist yönetim anlayışı gibi faktörlerin birleşimi Amerika'da Herbartçı geleneğin 1920'li yılların ortalarına doğru zayıflamasına neden olduğu görülmektedir. Özellikle 1800'lü yılların sonlarına değin yaklaşık olarak elli civarında Amerikalı eğitimcinin doktora çalışmasını yaptığı Almanya'nın büyük ve köklü üniversitelerinden (Halle, Leipzig, Jena gibi) mezun eğitimciler artık bu dönemde etkilerini kaybetmiş ve kendi kabuklarına çekilmişlerdir. Bu dönem artık felsefenin, tarihin değil doğa biliminin kurallarına göre işleyen bir eğitim biliminin çağıdır. Amerikalı eğitim tarihçisi Ellen C. Lagemann'ın ifadesi ile “20.yy.'da John Dewey’in kaybettiğini ve Edward L. Thorndike'ın kazandığını kabul etmeden Amerikan eğitim tarihini anlayamazsınız" sözü bu noktada çok anlamlıdır. (Lagemann, 1989, p.185). Thorndike'ın kazanması aynı zamanda program alanında da teknik bilimsel paradigmanın zaferi demekti ve dönemin Zeitgeist'i bunu zorunlu kılıyordu. Sekiz Yıl Çalışması bu açıdan bakıldığında program ve öğretime ilişkin sorunların ciddi bir şekilde ele alındığı önemli bir aşamadır. Fazla değil sadece on yıl sonra dünyada program alanında en etkili kitapların yazarları olan Ralph W. Tyler, Hilda Taba, Benjamin Bloom bu projede aktif olarak yer aldılar. Yine Tyler bu çalışmadan elde ettiği deneyimle program geliştirme modelini ileri sürdü. Tyler'ın program geliştirme modeli bütünü ile okul odaklı bir modeldir. Teknik bilimsel ve lineer boyutu çok net bir şekilde gösteren model öğrenme ve eğitimi davranış değişikliği bağlamında ele almakta ve eğitim psikolojisine hedeflerin tespit edilmesinde kritik bir rol vermektedir. Her ne kadar bu modelde eğitim felsefesi de bulunsa da burada felsefenin görevi yalnızca hedeflerin tutarlılık boyutunu ve önem sırasını belirlemektir. Tyler'ın 1949 yılında kaleme aldığı Eğitim Programlarının ve Öğretimin Temel illkeleri başııkı eserinde program geliştirme ile ilgili sorduğu sorular şunlardır: (1) Okulun gerçekleştirmek istediği eğitimsel amaçlar nelerdir? (2) Bu amaçlara ulaşabilmek için hangi öğrenme deneyimlerine ihtiyaç vardır? (3) Bu öğrenme deneyimleri etkili bir şekilde nasıl düzenlenebilir? (4) Bu amaçlara ulaşılıp ulaşılmadığını nasıı belirleriz? (Tyler, 1949, p.2). Tyler'ın soruları incelendiğinde bu soruların doğası gereği ölçmeye uygun olduğu, teknik uzmanlık gerektirdiği açıkça görülmektedir. Tyler sonrası dönemde özellikle Amerika'da öğretim tasarımı üzerine yapılan çalışmalar neredeyse her zaman Tyler Rasyonelini ele alarak modellerini kurgulamışlardır. Öğretim tasarım modellerinin temel amacı etkili bir öğrenme sürecinin gerçekleşmesi için öğretim sürecinin mantıksal-analitik bir şekilde sıralamaktır. Böylece öğretim sürecinin her bir adımı doğrusal olarak ve ilişkili bir şekilde tıpkı bir mühendislik projesi gibi tasarlanabilecektir. Bu ise daha az felsefe fakat daha fazla eğitim psikolojisi ve öğretim tasarımı demektir. 
Hopmann ve Riquarts (1995) program ve didaktik arasındaki farkı ders planlama, araştırma süreci ve kuram olarak üç boyutta incelemişlerdir. Üç ayrı seviyede her iki geleneğin sorduğu sorular iki geleneğin bakış açısını yansıtması noktasında önemlidir. Dersin planlanması sürecinde program temel olarak "nasıl" üzerine odaklanırken didaktik "ne" ve "niçin" sorularına odaklanmaktadır. Bir diğer ifade ile didaktik süreçte sorular aslında Bildung'un doğasına uygun şekilde sorulur. Bir diğer ifade ile Bildung her zaman merkezdedir. Tablo 1'de bu karşılaştırma verilmiştir.

Tablo 1.

Didaktik ve Program Geleneğinin Karşılaştırılması.

\begin{tabular}{lll}
\hline Seviye & Program & Didaktik \\
\hline 1. Ders Planlama & & \\
çekirdek soru & nasıl & ne ve niçin \\
içerik & nesne & örnek \\
amaçlar & görev (iş) & amaç (yön) \\
ders planı & ders eylemi & deneyim çerçeveleri \\
öğretim & uygulama & lisanslandırma (yetkinlik kazandırma)
\end{tabular}

2. Araştırmanın odak noktası

Başarılı öğretimin

değerlendirilmesi

\author{
Bireysel öğretmen \\ öğretmen düşünmesi \\ (yorumsal) \\ Öğrenci başarısı \\ (notlar \& başarı derecesi)
}

\author{
Öğretme sanatı, Didaktik \\ analiz (hermönitik) \\ profesyonel \\ uygunluk, \\ yansitma
}

Başlatma (intisap)

Bildung önce gelir işlev

sıralama hazırlık

ders konusu önce gelir

Kaynak: Westbury, I., Hopmann, S., \& Riquarts, K. (2000). Teaching as a reflective practice: The German Didaktik tradition. Mahwah, NJ: Lawrence Erlbaum Associates, s.18.

\section{Tartışma, Sonuç ve Öneriler}

Kıta Avrupası'nda gelişen didaktik gelenek kendine ait felsefi temelleri ve gelişim çizgisi ile Anglo-Amerikan program ve öğretim yaklaşımından farklı bir pedagojik geleneği temsil etmektedir. Bu pedagoji geleneği Comenius ve Raticus'un çalışmaları ile belli bir aşamaya gelmiş daha sonra J.F. Herbart'ın katkıları ile belirli bir sisteme kavuşmuştur. Bununla beraber didaktiği belli bir felsefi gelenek içinde yeniden yorumlayan Dilthey'ci pedagoji olmuştur. İnsanı konu alan bir bilim olarak pedagojinin doğa bilimleri benzeri bir yapı ile hareket etmesinin insanı anlama konusunda problemler yaşayacağını ileri süren Dilthey, pedagojiyi insanı tarihsel, kültürel ve sosyal bağlam içinde inceleyen bir insan bilimi olarak ele almıştır. Pedagojinin gelişimi için yapması gereken tarihsel açıdan sorunları irdelemek, anlamak ve yeniden yorumlamaktır. Felsefi bir pedagojinin temeli anlamaya dayalı hermenötik perspektiftir. Hümanist pedagoji olarak gelişmeye başlayan bu hareket özellikle Almanya'da oldukça sağlam bir mecrada ilerlemiş ve üniversitelerde kısa zamanda kendine geniş yer bulmuştur. Kuşkusuz bunun nedenleri içinde hümanist pedagojinin idealist felsefeye uzanan köklerinin katkısı inkâr edilmez. Alman romantizmi, Fichte, Herder ve Humboldt gibi düşünürlere dayalı olarak ilerleyen bu pedagoji kısa zamanda etkili bir duruma gelmiştir. 20. yüzyılın başlarından itibaren gelişmeye devam eden bu hareket her iki dünya savaşından sonra da etkisini sürdürmüştür. Temel problemi etkili ve verimli bir öğretim sürecini gerçekleştirmek olan didaktik, bu amacını felsefi bir bağlam içinde yaparak Amerikan eğitim bilim geleneğinden açık bir şekilde ayrılır. Didaktik gelenek içinde yer alan ve merkezi bir kavram olan Bildung, toplumsal yaşama kültürel açıdan uyum sağlamış ve kendi gerçekliğini idrak eden bireyleri yetiştirmeyi hedeflediği için didaktik doğası gereği felsefi olmak zorunda kalmıştır. Ikinci Dünya Savaşı'nın ardından Avrupa'da Amerikalaşmanın etkisi didaktik alanda da kendini göstermiş ve Amerikan eğitim bilimine yakın didaktik modeller ortaya çıkmıştır. Bununla beraber hümanist pedagojinin temsilcilerinden olan Wolfgang Klafki hümanist pedagoji geleneğini Frankfurt Okulu'nun eleştirel teorisi ile sentezleyerek yeni bir didaktik yapı ortaya koymuştur. Bu bakış açısı diğer didaktik modeller içinde özgün ve orijinalliği ile dikkat çekmektedir. Klafki'nin öne sürdüğü bu perspektifin özgünlüğü kuşkusuz köklerinin Dilthey'e kadar uzanmasında yatmaktadır. Altmışlı yılların sonlarına doğru 
Frankfurt Okulu ve eleştirel teorinin katkıları ile modelini daha fazla toplum bağlamında yenileyen Klafki, diğer didaktik öğretim modelleri ile kıyaslandı̆̆ında daha fazla felsefi ve sosyo pedagojik bir yönelimi temsil etmektedir.

Öyleyse böyle bir bakış açısının genel olarak program ve öğretim alanına katkıları neler olabilir? AngloAmerikan program ve öğretim anlayışının özellikle II. Dünya Savaşını takip eden yıllarda eğitim alanında genel kabul gören bir söylem olmasının temel nedeni Amerika'nın dünya hegemonyasında egemen güç haline gelmesinin yanında sonuç odaklı Amerikan eğitim bilimi perspektifinin özellikle kitlesel okullaşma, program ve öğretim alanında getirdiği teknik bilimsel paradigmanın kolay ve uygulanabilir çözümler sunmasıdır. Bu egemen söylem Amerikan hegemonyasının yükselişi ve soğuk savaş tehdidi ile daha da yaygınlaşmıştır. Öyle ki Almanya'da bile 60'lı yılların sonlarından itibaren Amerikan merkezli eğitim araştırması paradigması güçlenmeye başlamış ayrıca teknik bilimsel paradigmaya uygun didaktik modeller geliştirilmiştir. Bu açıdan bakıldığında Tyler Rasyoneli bu yükseliş sürecinin tacı olmuştur denilebilir. Bu yükseliş sürecine karşın program ve öğretim alanında bir krizin varlığı ilk defa Joseph Schwab tarafından dile getirilmiştir. Tyler Rasyoneli ve öğretim tasarım modellerinin altın çağını yaşadığı bir süreç içinde Schwab'ın eleştirileri ve önerdiği yapı her ne kadar genel anlamda bir kabul görmediyse de 70'li yıllardan itibaren entelektüel ağırlıklı Neo-Marxist ve Yeniden kavramsallaştırmacı gibi pedagojik hareketler için önemli bir temel olmuştur. Schwab öne sürdüğü teorik yapıda Alman didaktik geleneğine çok benzeyen bir model önermektedir. Alman hümanist pedagojisine dayalı didaktik Anglo-Amerikan program ve öğretim alanının yaşadığı kriz için bir çözüm olabilir miydi? Eğitim sürecinin odak noktasına hedefleri mi yoksa insanı mı yerleştirmek gerekiyordu? Taylorizm ve Fordizm gibi kitlesel üretimi hedefleyen yönetim yaklaşımları bağlamında gelişen Anglo-Amerikan program ve öğretim düşüncesi acaba insana dönük bazı noktaların üzerinde yeterince felsefi anlamda düşündü mü? Schwab'ın (1969:1) "mevcut yöntem ve ilkeleri ile işini yapamayan program alanındaki ciddi kriz alanın can çekişmesine neden oluyor; alanın acilen yeni ve daha etkili ilke ve yöntemlere ihtiyacı var" derken vurguladığı tam da bu noktadır.

Türkiye'deki program ve öğretim çalışmaları didaktik gelenekten ne kazanabilir? Türkiye'de teknik bilimsel program teorisinin oldukça güçlü temellere sahip olduğu açıktır. Türkiye'de özellikle 1960 sonrası dönemde bu konu ile ilgili yapılan yayınların ve eğitim fakültelerinde eğitim bilimleri bölümlerinin örgütlenmesi her zaman bu teknik bilimsel geleneğe göre yapıldığından ve master doktora programları da bu perspektif doğrultusunda tasarlandığından dolayı kıta Avrupası geleneğine ilişkin pedagojik söylemler oldukça sığ ve sessiz kalmış bir şekilde görmezden gelinmiştir. Hümanistik pedagojinin en önemli katkısı eğitimi sadece pozitivist bir bağlamın egemenliğinde değil tam tersine insan odaklı bir boyuttan ve insanı özne yapan bir perspektiften algılanması gerektiğine ilişkin bakış açısının önemine yaptığı vurgudur. Kıta Avrupası didaktik geleneği ve hümanist pedagoji aynı zamanda hermenötik, fenomenolojik analiz gibi yöntemlerle öğrenme ve öğretme sürecinin doğasına ilişkin kapsamlı analizlerin yapılmasına katkı sağlayarak alanı salt bir mühendislik alanı olmaktan kurtarabilir. Didaktik gelenek içinde hümanist pedagoji çizgisinde gelişen didaktik yaklaşımın öğrenme, öğretim, okul, kültür gibi kavramlara yönelik olarak oluşturduğu anlam ağının Türkiye'deki program çalışmaları için de ayrı bir katkı ve zenginlik sağlayacağı ileri sürülebilir. Pedagojiyi birbirinden ayrı parçalar halinde değil, fakat insan denilen fenomeni inceleyen bütüncül bir alan olarak ele almak belki de didaktik geleneğin program ve öğretim alanına kazandıracağı ilk kazanımdır. Bir diğer önemli kazanım da eğitimi sadece öğrenme ve öğretme süreci ile değil tam tersine öğrenme ve öğretme sürecini etkileyen farklı değişkenleri farklı disiplinler aracılığı ile inceleyerek öğretim sürecine katkı sağlamasıdır. Sadece teknik yönergelerle ve nasıl sorusu ile değil fakat anlam odaklı ve niçin sorusu eşliğinde eğitim ve eğitime ilişkin kavramlara yaklaşılabilir ve çok boyutlu analizler yapılabilir. Öğretim sürecine ilişkin farklı analizler belki de yaşanılan kriz durumlarının çözülmesine katkı sunabilir. Örneğin PISA sınavındaki başarısızlığın nedenleri salt teknik sıkıntılarla değil belki de öğretmen ve öğrenci arasındaki ilişkinin doğasının çözümlenmesi ile farklı bir şekilde kavranabilir. Sonuç olarak hem Anglo-Amerikan program ve öğretim düşüncesinin hem de didaktiğin aynı sorunlar üzerinde farklı yöntemlerle farklı cevaplar buldukları söylenebilir. Her iki geleneğin de ortak noktası öğretim sürecini etkili ve verimli yapma çabasıdır. Bu çalışmada problem sadece didaktiğin gelişiminin tarihsel seyri ile sınırlı olduğu için farklı didaktik modeller incelenmemiştir. Ayrıca didaktik ile program arasındaki diyalog da bu çalışmada çok ayrıntılı olarak işlenmemiştir. Çeşitli didaktik modelleri ile ilgili daha fazla çalışma yapılması Türkiye'de az bilinen bu pedagojik geleneğin daha yaygın biçimde tanınması ve takdir görmesi açısından faydalı olacaktır. 


\section{References}

Antel, S. C. (1952). Umumi didaktik. İstanbul: Doğan Kardeş Yayınları.

Baki, A. (2010). Öğretmen eğitiminin lisans ve lisansüstü boyutlardan değerlendirilmesi. Inönü Üniversitesi Eğitim Fakültesi Dergisi, 11(3), 15-31.

Baştürk Şahin, B., Şahin, G. \& Tapan Broutin, M. S. (2017). Didaktik durumlar teorisi ışığında asal sayılar kavramının öğretimi: Bir eylem araştırması. Necatibey Eğitim Fakültesi Elektronik Fen ve Matematik Eğitimi Dergisi (EFMED), 11(2), 156-171.

Biesta, J. J. G. (2013). On the idea of educational theory. In Baverly J.Irby, Genevieve Brown, Rafael Lara-Alecio \& Shirley Jackson (Eds.), The handbook of educational theory. (pp.5-16). NC: Information Age Publishing.

Blackbourn, D. (1998). The long nineteenth century: A history of Germany 1780-1918. New York: Oxford University Press.

Bulhof, N.I. (1980). Wilhelm Dilthey: A hermeneutic approach to the study of history and culture. MA: Martinus Nijhoff Publishing.

Comenius, A J. (1907). The great didactic. London: Adam \& Charles Black.

Copleston, F. (1962). A History of philosophy. (Vols. 1-3). New York: Doubleday and Co. Inc.

Danner, H. (1994). Bildung: A basic term of German education. Retrieved from: http://www.helmutdanner.info/pdfs/German_term_Bildung.pdf

Deng, Z. (2015). Content, Joseph Schwab and German Didaktik. Journal of Curriculum Studies, 47(6), 773-786. Retrieved from: http://dx.doi.org/10.1080/00220272.2015.1090628

Deng, Z. (2016). Bringing curriculum theory and didactics together: A Deweyan perspective, Pedagogy, Culture \& Society, 24(1), 75-99. Retrieved from: https://doi.org/10.1080/14681366.2015.1083465

DeWulf, M. (1959). The System of Thomas Aquinas._New York: Dover Publishing Co.

Egemen, Z.B. (1965). Terbiye IIminin Problemleri ve Terbiye Felsefesi. Ankara: AÜIFY.

Goodson, F.I. (2004). Understanding curriculum change: Some warnings about restructuring initiatives. In Fernando Hernandez \& I. F. Goodson (Eds.), Social geographies of educational change. (pp.15-28). Dordrecht: Kluwer Academic Publishing.

Gök, M. \& Erdoğan, A. (2017). Sınıf Ortamında Rutin Olmayan Matematik Problemi Çözme: Didaktik Durumlar Teorisine Dayalı Bir Uygulama Örneği. YYÜ Eğitim Fakültesi Dergisi, 14(1), 140-181. http://efdergi.yyu.edu.tr

Gundem, B. B. (2000). Understanding European didactics. In B. Moon, M. Ben-Peretz, \& S. Brown (Eds.), Routledge international companion to education (pp. 235-262). London: Routledge.

Gundem, B.B. (1992). Vivat Comenius: A commemorative essay on Johann Amos Comenius. Journal of Curriculum and Supervision, 8(1), 43-55.

Gutas, D. (1999). Greek thought, Arabic culture: The Graeco-Arabic translation movement in Baghdad and early Abbasid society. London: Routledge.

Gutek, L.G. (2013). An historical introduction to American education. (Third Edition). Illinois: Waveland Press.

Herbart, F.J. (1904). Outlines of educational doctrine. (A.F. Lange, Trans). New York: The MacMillan Company.

Hilgenheger, N. (1993). Johann Friedrich Herbart. Prospects: The Quarterly Review of Comparative Education, XXIII, 3/4, 649-664.

Hodgson, M. G. S. (1974). The venture of Islam: Conscience and history in a world civilization (Vol. 1). Chicago: Chicago University Press.

Hopmann, S. (2007). Restrained teaching: the common core of didaktik. European Educational Research Journal,6 (2), 109-124.

Jarvis, P. (2006). The Socratic method. In Peter Jarvis (Ed.), The theory and practice of teaching. (pp.90-97). Second Edition. New York: Routledge.

Kansanen, P. (1995a) The Deutsche didaktik. Journal of Curriculum Studies, 27(4), 347-352. http://dx.doi.org/ 10.1080/0022027950270401

Klafki, W. (1998). Characteristics of critical-constructive Didaktik. In B.B Gundem \& Stefan Hopmann, (Eds.), Didaktik and/or Curriculum-An International Dialogue (pp.307-330). New York: Peter Lang Publishing.

Klafki, W. (1995) [1958] Didactic analysis as the core of preparation of instruction, Journal of Curriculum Studies, 27 (1), 13-30. 
Kruger, R. A. (2008). The significance of the concepts "elemental" and "fundamental" in didactic theory and practice. Journal of Curriculum Studies, 40, 215-250.

Künzli, R. (1998). The common frame and the places of Didaktik. In B. B. Gundem \& S. Hopmann (Eds.), Didaktik and/or curriculum: An international dialogue (pp. 29-45). New York, NY: Peter Lang.

Künzli, R. (2013). Memorizing a memory: Schwab's the practical in a German context. Journal of Curriculum Studies, 45, 668-683.

Lagemann, C. E. (1989). The plural worlds of educational research. History of Education Quarterly, 29 (2), $185-$ 214.

Leek, J. (2011). John Amos Comenius: The initiator of modern language teaching and world understanding. Prace Naukowe Akademii, 7, 223-232.

Levinger, M. (2000). Enlightened nationalism: The transformation of Prussian political culture 1806-1848. New York: Oxford University Press.

Lindberg, C.(2010). The European reformations. Main Street, Malden: Blackwell Publishing.

Lukaš, M. \& Munjiza, E. (2014). Education system of John Amos Comenius and its Implications. Život i škola, 31, 32-44.

Makdisi, G. (1981). The rise of colleges: Instutions of learning in Islam and the West. Edinburgh: Edinburgh University Press.

McNeil, D. J. (2015). Contemporary curriculum: In thought and action. (Eighth Edition). NJ: Wiley.

Menck, P. (2014). Johann Amos Comenius. In D.C.Philips (Ed.), Encyclopedia of educational theory and philosophy.(pp. 155-157). California: Sage Publishing.

Nohl, H. (1949). Pädagogik aus dreißig jahren. Frankfurt am Main: Schulte- Bulmke.

Ohles, F.J. (1978). Biographical dictionaries of American educators. Westport: Greenwood Press.

Pinar, F.W. Reynolds, M.W, Slattery, P, Taubman, M.P. (2008). Understanding curriculum: An introduction to the study of historical and contemporary curriculum discourses. New York: Peter Lang.

Roest, B. (2000). A history of Franciscan education. Leiden: Brill.

Rorem, P. (1999). Hugh of Saint Victor. New York: Oxford University Press.

Saliba, G. (2007). Islamic science and the making of the European renaissance. Cambridge, MA: MIT Press.

Schwab, J. J. (1969). The practical: a language for curriculum. School Review, 78(1), 1-23.

Siljander, P. \& Sutinen, A. (2012). Introduction. In Pauli Siljander, Ari Kivela \& Ari Sutinen (Eds.), Theories of bildung and growth: Connections and controversies between continental and educational thinking and American pragmatism. (pp. 1-18). Roterdam: Sence Publishers.

Spranger, E. (1968). Grundlegende bildung, berufsbildung, allgemeinbildung. Berufsbildung und allgemeinbildung. Heidelberg. $\quad$ Retrieved http://www.helmutdanner.info/pdfs/German_term_Bildung.pdf

Tahirsylaj, A. (2017). Curriculum field in the making: Influences that led to social efficiency as dominant curriculum Ideology in progressive era in the U.S. European Journal of Curriculum Studies, 4, (1), 618-628.

Tröhler, D. (2003). The discourse of German Geisteswissenschaftliche Pädagogik: A contextual reconstruction, Paedagogica Historica, 39 (6), 759-778. https://doi.org/10.1080/0030923032000128890

Tyler, W.R. (1949). Basic principles of curriculum and instruction. Chicago: University of Chicago Press.

Van Manen, M. (2015). Pedagogical tact: Knowing what to do when you don't know what to do. New York: Routledge.

Westbury, I., Aspfors, J., Fries, A.V., Hansén, S.E., Ohlhaver, Frank., Rosenmund, M. \& Sivesind, K. (2016) Organizing curriculum change: an introduction, Journal of Curriculum Studies, 48 (6), 729-743, Retrieved from: http://dx.doi.org/10.1080/00220272.2016.1186736

Westbury, I., Hopmann, S., \& Riquarts, K. (2000). Teaching as a reflective practice: The German didaktik tradition. Mahwah, NJ: Lawrence Erlbaum Associates.

Wulf, C. (2014). Educational science. In D.C.Philips (Ed.), Encyclopedia of educational theory and philosophy. (pp. 270-273). California: Sage Publishing.

Yıldırım, A. \& Şimşek, H. (2008). Sosyal Bilimlerde Nitel Araştırma Yöntemleri. (Onuncu Baskı). İstanbul: Seçkin Yayıncılık. 
Yıldırım, İ. \& Vural, Ö. F. (2014). Türkiye'de Öğretmen Yetiştirme ve Pedagojik Formasyon Sorunu. Journal of Teacher Education and Educators, 3(1), 73-90.

Yurdatapan, M. \& Şahin, F. (2012). İlköğretim Fen Ve Teknoloji Dersi Genetik Ünitesinde Öğretmen Bilgilerinin "Didaktiksel Dönüşüm Teorisi" Yaklaşımıyla Değerlendirilmesi. Ondokuz Mayıs Üniversitesi Eğitim Fakültesi Dergisi, 31(1), 294-324.

Zierer, K \& Seel, M.N. (2012). General Didactics and Instructional Design: Eyes like twins a transatlantic dialogue about similarities and differences, about the past and the future of two sciences of learning and teaching, p.7. Retrieved from: https://springerplus.springeropen.com/track/pdf/10.1186/2193-1801-1-15. 
